\title{
Response of Forest to Climatic Events and Human Management at Fort Leavenworth, Kansas
}

\author{
James S. Aber ${ }^{1}$, Juliet Wallace ${ }^{2}$, and Matthew C. Nowak ${ }^{3}$ \\ ${ }^{1}$ Earth Science Department, Emporia State University, Emporia, Kansas 66801 (email: aberjame@emporia.edu); \\ ${ }^{2}$ Department of Geography, University of Waterloo, Waterloo, Ontario, Canada N2L 3G1; ${ }^{3}$ Natural Resources, Fort \\ Leavenworth, Kansas 66027.
}

\begin{abstract}
Characteristics and temporal changes in forest cover from 1987 to 1997 were documented on the basis of remote sensing for two study forests at Fort Leavenworth, northeastern Kansas. Eight Landsat 5 Thematic Mapper (TM) datasets from the month of July cover the study period, which included a major drought in 1988-1989 and flooding along the Missouri River in 1993. Other data sources included kite aerial photographs, digital orthophotos, tree-ring cores, climatic records, and ground observations. Three study areas were evaluated from Landsat TM datasets: (1) the entire Fort Leavenworth area; (2) an upland, hardwood forest composed mainly of oaks; and (3) a bottomland, softwood forest dominated by cottonwood. Normalized Difference Vegetation Index (NDVI) values were derived from these three study sets and subjected to image differencing and principal-component analysis. The TM band 5:4 ratio was also analyzed for the two study forests. Values and trends derived from Landsat imagery were compared to data on tree-ring growth in upland oaks and regional climatic events.

Annual growth of tree rings in upland oaks is tied closely to precipitation and the Palmer Drought Severity Index (PDSI); however, changes in NDVI values lag one to two years behind the onset of climatic events, particularly drought episodes. During the first year of drought (1988), vegetation cover in the upland and bottomland forests reacted in different ways: with a slight decline in the upland forest and a slight increase in the bottomland forest. The increased vegetation in the bottomland forest presumably resulted from more understory growth in dry hollows and potholes. In the second year of drought (1989), both forests suffered a marked decline in vegetation cover. NDVI values reached their minima for all categories (whole area, upland forest, and bottomland forest) in 1990 , even though precipitation and tree-ring growth increased substantially that year. We conclude that changes in Landsat-derived NDVI values are out of phase with climatic events and variations in tree-ring growth for both upland and bottomland forests in northeastern Kansas and northwestern Missouri.

Overall change (1987 to 1997) for NDVI values is down slightly for all categories of evaluation. This probably reflects reduced precipitation throughout the study period compared to the long-term average. Changes in vegetation took place mainly on the forest margins. Such changes are thought to result from microclimatic stress at forest edges. The bottomland study forest also was impacted by severe flooding in 1993. Routine human activities may have resulted in minor changes along the margins of both study forests. The bottomland forest was affected by intentional burning of the adjacent prairie in April 2000. Cottonwood trees at the forest edge were killed or injured by the prairie fire, which penetrated the forest understory some distance.
\end{abstract}

In 1996, we began research on applications of remote sensing for evaluation of forest cover in northeastern Kansas. We selected two study forests on the Fort Leavenworth military reservation. The first is an upland forest composed of oaks and other hardwood species; the second is a bottomland forest of cottonwood and other softwoods on the Missouri River floodplain. Although managed in somewhat different ways, both forests experienced minimal human impact during the past two decades. The goal of our investigation was to establish relationships between satellite observations of vegetation, actual growth of trees, and climatic events of the past three decades. We employed Landsat Thematic Mapper (TM) datasets as our primary source of remotely sensed information for the period 1987 to 1997 . These datasets were supplemented on the ground with kite aerial 
photography (KAP), tree-ring analysis of the upland forest, climatic records for northeastern Kansas, and various ancillary data on geology, soils, and topography.

The study period included a major drought in 19881989 and the 1993 flooding of the Missouri River, which completely innundated the bottomland. The study, thus, spans years of climatic extremes as well as near-normal intervals. The study revealed complicated and unexpected relationships between climatic events, response of forest growth, and satellite observations (Aber et al., 1998; Wallace, 2000). These results have important implications for use of satellite imagery in the interpretation of vegetation cover and environmental conditions for similar forest types in the central United States.

\section{Study Area}

The study forests are located on the Fort Leavenworth military reservation, immediately north of the city of Leavenworth in northeastern Kansas (fig. 1). The upland forest occupies a bedrock ridge in the western portion of the military reservation, and the bottomland forest is located within a large meander loop of the Missouri River (fig. 2). The region ranges in elevation from $232 \mathrm{~m}$ (760 feet) on the Missouri River to $332 \mathrm{~m}$ (1,090 feet) at Hancock Hill in the upland forest. The bottomland forest includes approximately 550 hectares (1,360 acres) and is relatively continuous in coverage. The upland forest, in contrast, is somewhat disjunct; it is broken by openings for roads, buildings, and other structures. The upland forest covers about 400 hectares (990 acres).

An ecological survey of the Fort Leavenworth vicinity was carried out by Brumwell (1951), who described the types of forest on the military reservation; the forests were further documented by Kuchler (1974). More recently, detailed mapping by the State Biological Survey of Kansas provided a comprehensive inventory of plant and animal species on the military reservation (Freeman et al., 1997).

The upland forest is composed of two portions (fig. 3). The main portion is classified as Quecus alba-Carya ovata/Ostrya virginiana (white oak-shagbark hickory) forest (Freeman et al., 1997). A smaller portion is identified as Acer saccharum-Tilia americana-Quercus rubra/Ostrya virginiana (maple-basswood) forest. The upland study forest represents a mature vegetation succession that has existed for 150-200 years. It is composed of drought-resistant trees including white oak, northern red oak, burr oak, bitternut, and shagbark hickory. Other trees in the upland forest are American elm, green ash, box elder, backbrush, hackberry, basswood, pecan, silver and sugar maple, sycamore, walnut, and redbud. Small tracts of native (warm-season) and introduced (cool-season) prairie exist within the upland forest. Also present within the upland forest are roads, buildings, water tanks, and other structures.

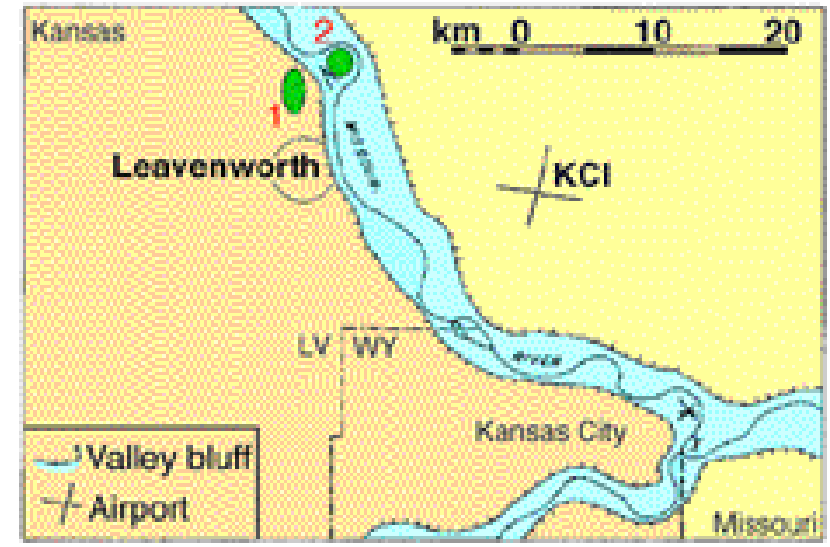

FIGURE 1. General location map for study forests at Fort Leavenworth, Kansas: 1 = upland, hardwood forest, 2 = bottomland, softwood forest (adapted from Aber et al., 1999).

The bottomland forest also is composed of two types (fig. 3). The first is classified as-Populus deltoidesPlatanus occidentalis (cottonwood-sycamore) forest and the second as Carya illinoensis-Celtis laevigata (pecansugarberry) forest (Freeman et al., 1997). These forests are composed primarily of cottonwood and pecan. Other trees include box elder, red mulberry, green ash, and American elm. Sugarberry is not present; it is replaced by hackberry. The forest floor is swampy with open, waterlogged zones in old meander scrolls. The bottomland forests at Fort Leavenworth are believed to be the largest old-growth stands remaining in the lower Missouri River valley (Freeman et al., 1997). These forests have developed in a dynamic river system that floods periodically, most recently in 1993 when the Missouri River completely innundated the Fort Leavenworth bottomland. The 1993 flood was the greatest of historical record in many portions of the lower Missouri River valley. New trees now flourish on the flooded areas.

The study area is part of the glaciated region of northeastern Kansas. Unconsolidated surficial sediments include Pleistocene till and loess on uplands and Holocene alluvium in the stream valleys (fig. 4). Underlying bedrock is composed of alternating layers of limestone, sandstone, and shale of Pennsylvanian age. The high ridge in the western portion of the military reservation is supported by the Oread Formation of the Shawnee Group. The Oread includes thick limestone members that are relatively resistant to erosion. Lower portions of the study area are underlain by softer shale and sandstone of the Douglas Group. The upland study forest is associated mainly with the Knox and Gosport soil complexes (fig. 5), which developed from loess, till, and weathered bedrock. They are located on moderately to steeply sloping portions of the topographic ridge in the western portion of the military reservation. The 


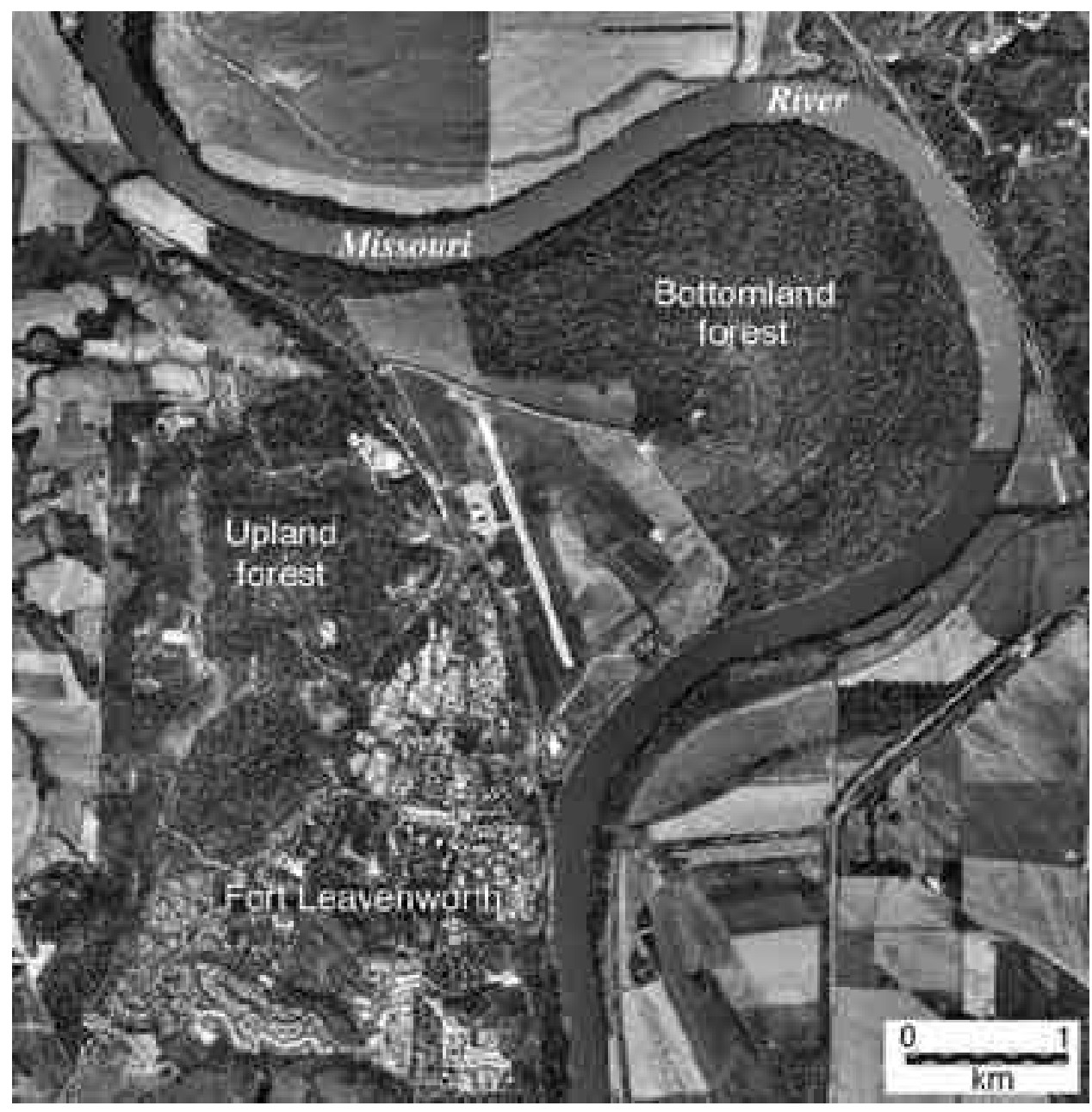

FIGURE 2. Orthophotograph of the study area at Fort Leavenworth, Kansas. Data from the Kansas Geological Survey.

bottomland study forest grows mainly on Onawa soils in alluvial sediment of the floodplain.

The climate of northeastern Kansas is continental with distinct seasons. Mean annual temperature is about $54^{\circ} \mathrm{F}$ $\left(12^{\circ} \mathrm{C}\right)$; temperature extremes range from more than $100^{\circ}$ $\mathrm{F}\left(38^{\circ} \mathrm{C}\right)$ to less than $0^{\circ} \mathrm{F}\left(-18^{\circ} \mathrm{C}\right)$. Daily temperature fluctuations of $35^{\circ} \mathrm{F}\left(20^{\circ} \mathrm{C}\right)$ or more can happen any time during the year. Average annual precipitation is around $90 \mathrm{~cm}$ (35 inches). Most precipitation is received in spring and early summer (April-July) with a second wet season in the autumn (October-November) of some years. The mean annual precipitation (January-December) for the study area for the period 1987-1997 was $74 \mathrm{~cm}$ (29 inches), well below the long-term average (NCDC, 1999).

\section{Previous Research}

With the successful launch in 1972 of the Landsat satellite series, much scientific research has focused on the identification, classification, interpretation, and mapping of vegetation for local, regional, and global applications in earth-system science. Following Landsat, many more satellite systems have been designed and operated for monitoring vegetation conditions on the land portions of the Earth's surface. The use of satellite remote sensing for monitoring vegetation is now a core priority within NASA's Earth Observing System for understanding global climatic change (Asrar and Dozier, 1994).

Photosynthetically active land vegetation strongly absorbs red $(0.6-0.7 \mu \mathrm{m})$ light and strongly reflects nearinfrared $(0.7-1.0 \mu \mathrm{m})$ energy. It is the only common landcover material with this spectral signature (Colwell, 1974). Many vegetation indices have been derived based on numerical combinations of red and near-infrared values in remotely sensed datasets (Tucker, 1979; Perry and Lautenschlager, 1984). The most widely used vegetation index is the Normalized Difference Vegetation Index (NDVI), introduced by Rouse et al. (1974) and now a standard method for vegetation analysis: NVDI $=$ Nearinfrared - Red / Near-infrared + Red (Price and Bausch, 1995).

NDVI values range from -1 to +1 . Positive values represent active vegetation, and near-zero or negative values represent other types of materials: bare soil/ sediment, bedrock, concrete/asphalt, water bodies, snow/ 


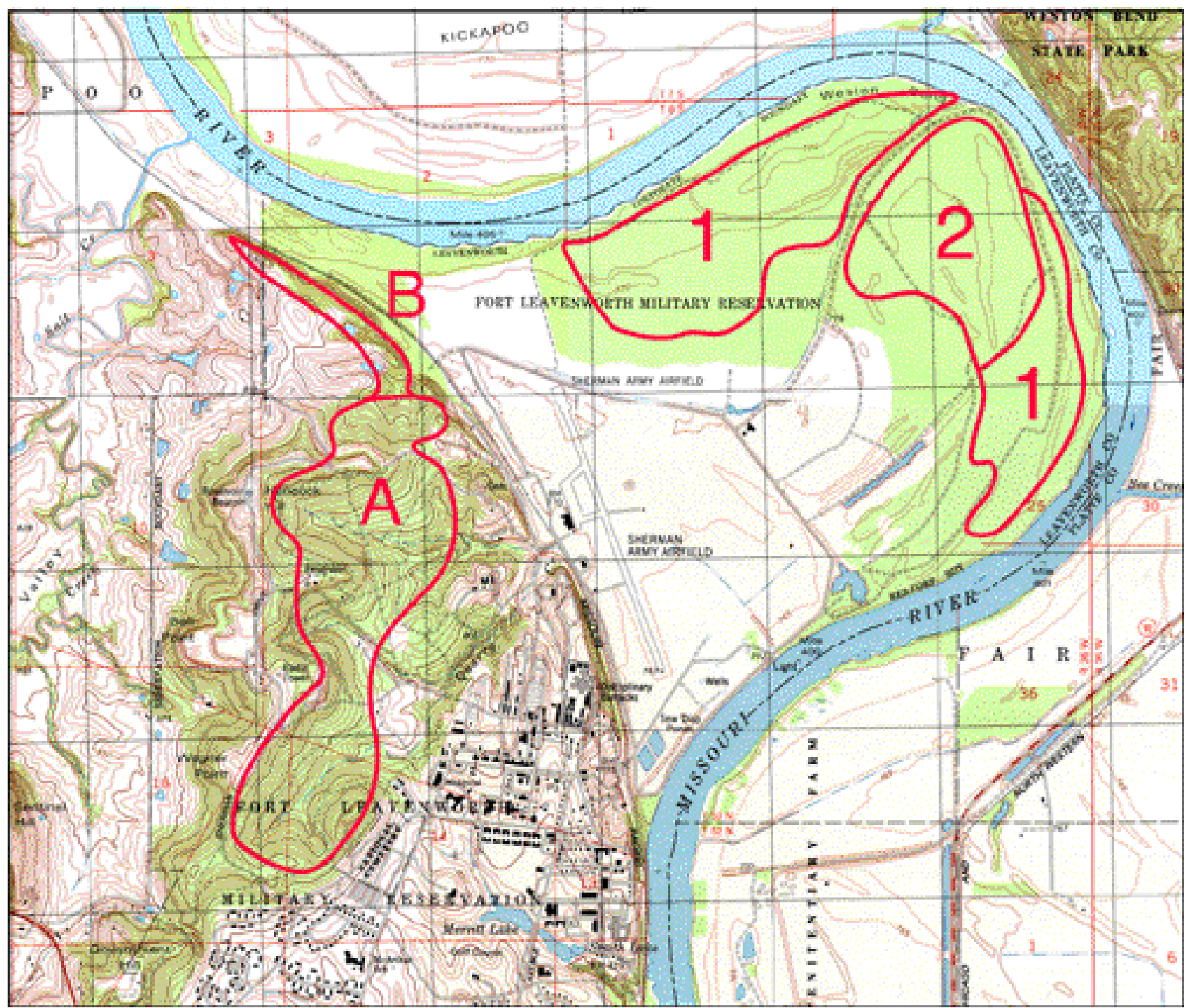

Figure 3. Composition of study forests at Fort Leavenworth. A = upland white oak-shagbark hickory forest, B = upland maplebasswood forest, 1 = bottomland cottonwood-sycamore forest, 2 = bottomland pecan-sugarberry forest (adapted from Freeman et al., 1997).

ice, and clouds. Early work revealed that plants under stress show reduced reflectivity in the infrared spectrum (Gates et al., 1965; Allen and Richardson, 1968). Further research has shown that moisture content in plant leaves is indicated by the ratio of mid-infrared $(1.3-2.5 \mu \mathrm{m})$ to near-infrared reflectivity (Tucker, 1980; Carter, 1991). On this basis, a moisture-stress index (MSI) has been utilized to detect drought and other stress conditions in vegetation and is intended to detect decreased water content in leaf foliage: MSI = Mid-infrared $/$ Nearinfrared (Rock et al., 1986; Hunt and Rock, 1989; Cibula et al., 1992).

In a preliminary analysis of Landsat TM datasets for the Fort Leavenworth upland forest (Wilkins, 1997), NDVI values for spring, summer, and autumn for 1987 , 1988, 1990, and 1994 were examined and compared to climatic records and tree-ring data. Wilkins (1997)

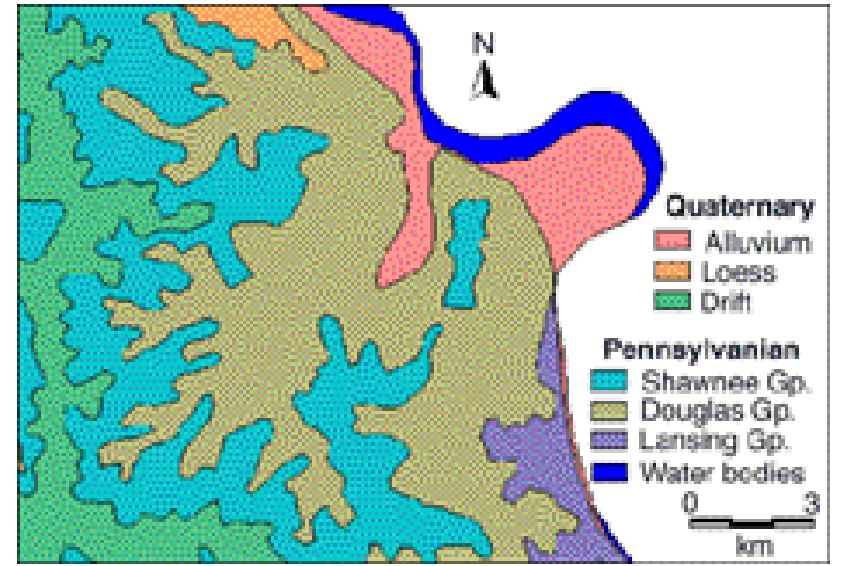

FIGURE 4. Generalized geology of the study area. Based on data (1999) from DASC, Kansas Geological Survey. 


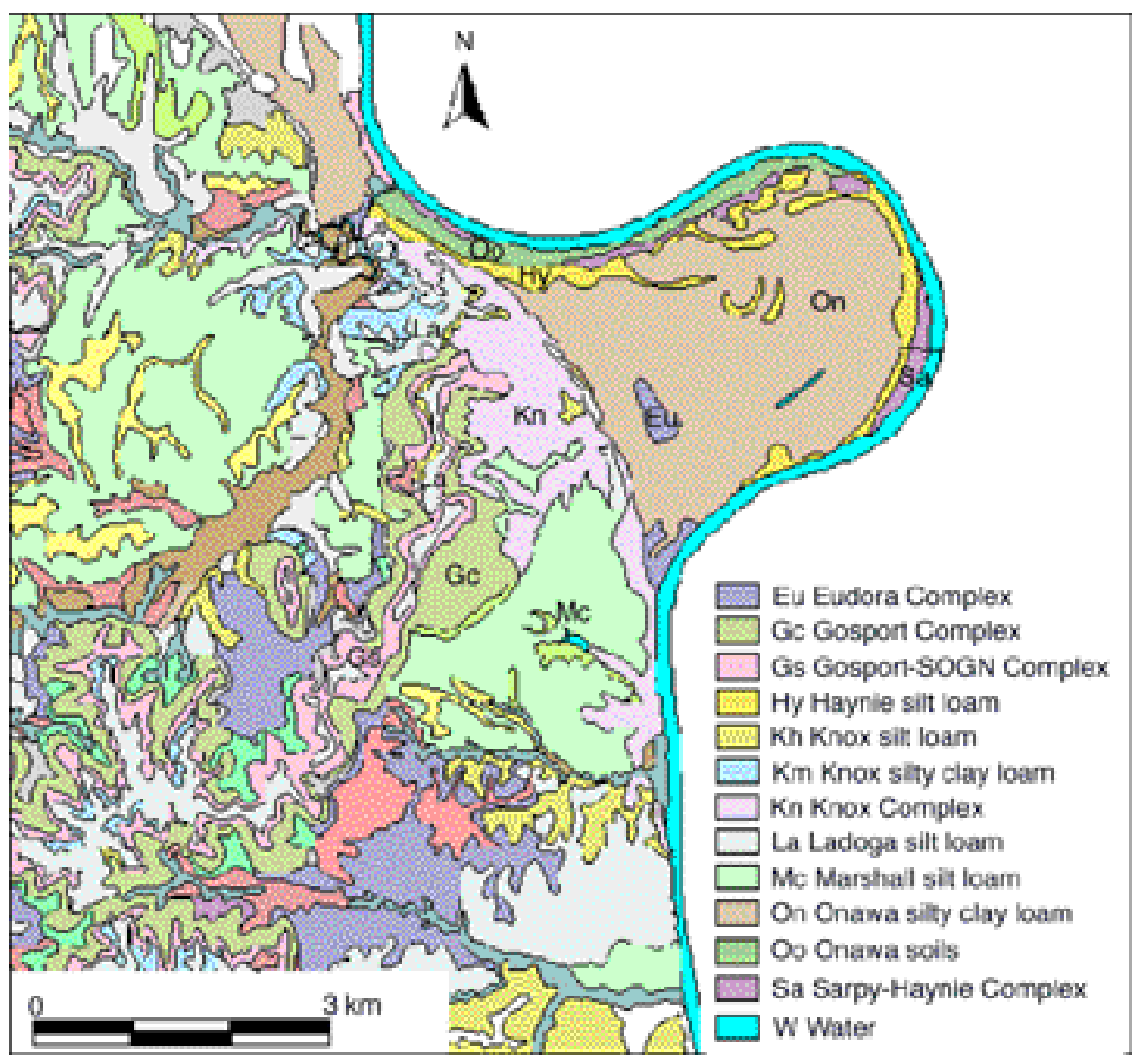

FIGURE 5. Soils map of the study area. Based on data (1999) from DASC, Kansas Geological Survey.

identified a one- to two-year lag between the drought of 1988-1989 and decline in forest NDVI values. In another study based on AVHRR data, Wang et al. (2001) examined biweekly trends in NDVI, temperature and precipitation during a 9-year period (1989-1997) for the state of Kansas. They found that deviations in average precipitation corresponded to most spatial and year-toyear variations in NDVI values; however, temperature deviations from average generally were not correlated with NDVI variations. They concluded that precipitation is a strong indicator for regional patterns of NDVI and vegetation productivity.

Dendroclimatology is based on analysis of tree-ring records. Variations in tree-ring width are highly correlated with availability of moisture in soils (Fritts, 1976), and dendroclimatology has been studied in several parts of the U.S. Great Plains (Stockton and Meko, 1975; Blasing and Duvick, 1984; Cook et al., 1988). In an investigation of the tree-ring record for oak species in the upland forest at Fort Leavenworth, Nang (1998) found that tree-ring width is correlated strongly with the Palmer Drought Severity Index (PDSI), a common climatic index for drought conditions (Palmer, 1965), but not strongly correlated with either precipitation or temperature alone. Nang (1998) concluded that growth of tree rings responds in the same year to available moisture. NDVI values derived from Landsat TM datasets, however, do not show a direct relationship to tree-ring width or PDSI values (Nang, 1998).

In similar studies elsewhere, Davenport and Nicholson (1990) utilized NDVI values to analyze various types of vegetation in East Africa. They found that NDVI values are sensitive to rainfall in dry areas, but a significant lag period was noted for wet forests. In the southeastern United States, Pinder and McLeod (1999) found rather weak correlations among decreased rainfall, tree-ring growth, and MSI values for longleaf pine. These results taken collectively indicate that complicated relationships exist between climatic events, tree growth, forest canopy, and NDVI values determined from satellite imagery. Climatic events may result in immediate responses for some tree-growth factors, whereas responses may be delayed by one or two years for other factors. Furthermore, the nature of forest response to climatic events may vary with different tree species and environmental settings. 
6 Aber, Wallace, and Nowak

TABLE 1. Landsat $5 \mathrm{TM}$ datasets selected for use in this study.

Each dataset was acquired in July of the respective year.

\begin{tabular}{cc}
\hline Scene ID & Year \\
\hline LT5027033008720410 & 1987 \\
LT5027033008820710 & 1988 \\
LT5027033008920910 & 1989 \\
LT5027033009019610 & 1990 \\
LT5027033009119910 & 1991 \\
LT5027033009218610 & 1992 \\
LT5027033009419110 & 1994 \\
LT5027033009718310 & 1997 \\
\hline
\end{tabular}

\section{Methodology}

Processing and statistical analysis of Landsat TM datasets were the major methods used in this study. Other techniques included kite aerial photography (KAP), treering measurements, and analysis of climatic records. These lines of evidence were compared to discover

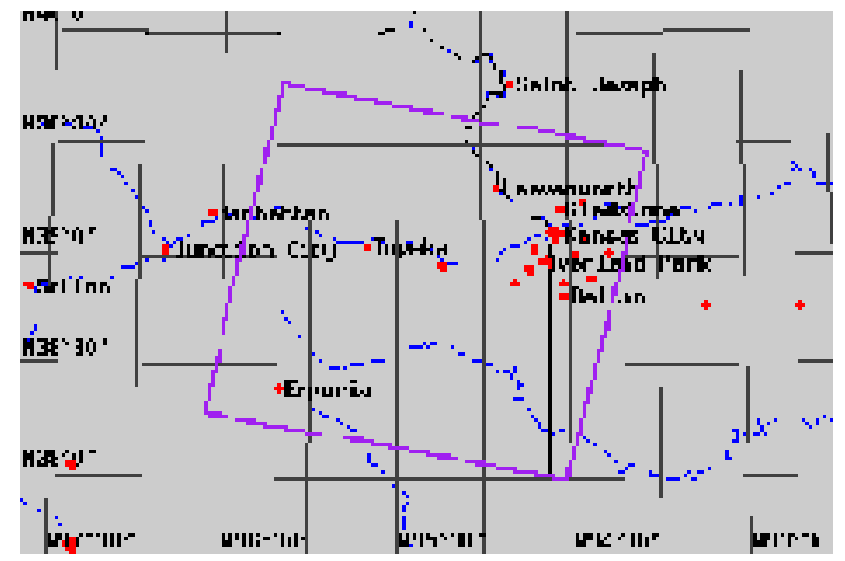

FIGURE 6. General location map for Landsat TM path 27, row 33. Map obtained from U.S. Geological Survey, EROS Data Center, Sioux Falls, South Dakota (1999).

temporal relationships between forest growth, climatic events, and satellite observations.

\section{Landsat TM Data Processing}

A total of eight Landsat TM datasets were obtained for the period 1987 to 1997 (table 1). To maintain the most

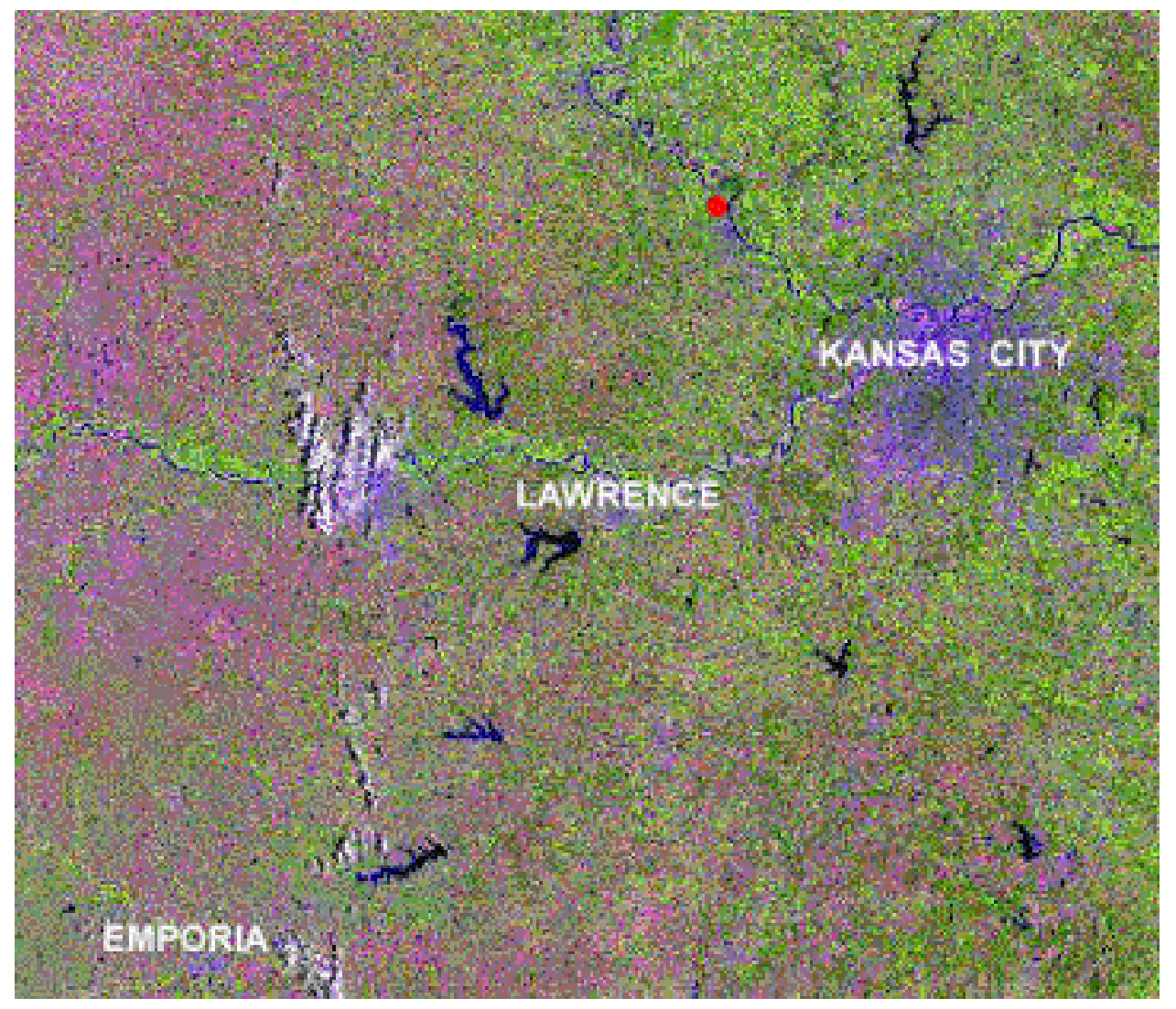

FIGURE 7. Landsat TM composite browse image (23 July 1987) made from bands 3, 4, and 5, color coded as blue, green, and red. Location of the Fort Leavenworth study area indicated by red dot. Active vegetation appears in various green and yellow-green colors. Image obtained from U.S. Geological Survey, EROS Data Center, Sioux Falls, South Dakota. 


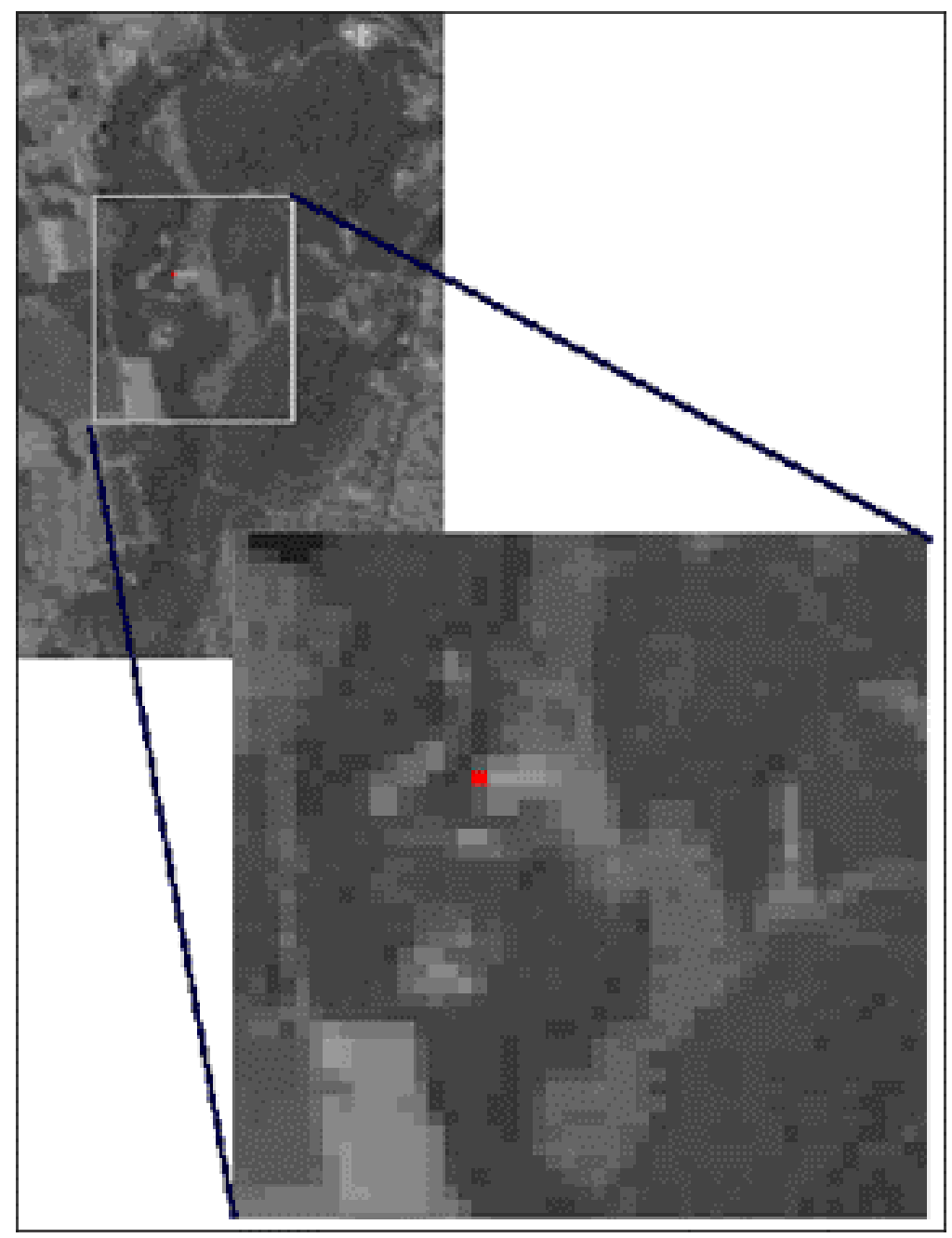

FIGURE 8. Landsat TM band 5 image showing old missile base in the upland study forest. This site (red pixel) was the reference point used for extracting windows from whole Landsat TM datasets.

consistent results for interannual comparison, all datasets were acquired by the Landsat $5 \mathrm{TM}$ instrument, and all Landsat TM datasets were from the month of July. Use of images from the same time each year should minimize seasonal effects on vegetation phenology, soil moisture, sun angle, and other variables. During July, vegetation is in full growth, prior rainfall is generally high, and sun position is high for good illumination of the forest canopy with minimal shadows. Most images used in this study were free of clouds in the study area, except for July 1989 and, to a lesser extent, July 1992. Because of heavy cloud cover throughout the summer of 1993, it was not possible to obtain an image of the study area for July 1993 . The selected scenes are from Landsat TM path 27, row 33, which includes northeastern Kansas and a small portion of northwestern Missouri (figs. 6, 7).

The study employed standard image-processing techniques, including haze correction, georegistration, compositing, ratioing, supervised and unsupervised classification, masking, principal-component analysis, and other operations (Avery and Berlin, 1992; Jensen, 1996).
All image processing and analysis was carried out with IDRISI software. Working image windows of the Fort Leavenworth area were extracted from the full scenes using a common reference point for all datasets: an old missile base within the upland study forest (fig. 8). These windows were resampled based on ground control points within and west of the military reservation (fig. 9). For control points within the reservation, differential GPS equipment was used for field survey of UTM coordinates (Wilkins, 1997). Locations of control points to the west were derived from digital topographic maps. Resampling resulted in working images in UTM projection, zone 15, NAD27 datum. All subsequent image processing was based on these resampled windows of the Fort Leavenworth study area.

\section{Landsat TM Data Analysis}

Whole-study scene NDVI values were calculated for haze-corrected windows based on Landsat TM band 4 (near infrared) and band 3 (red). Raw NDVI values are 


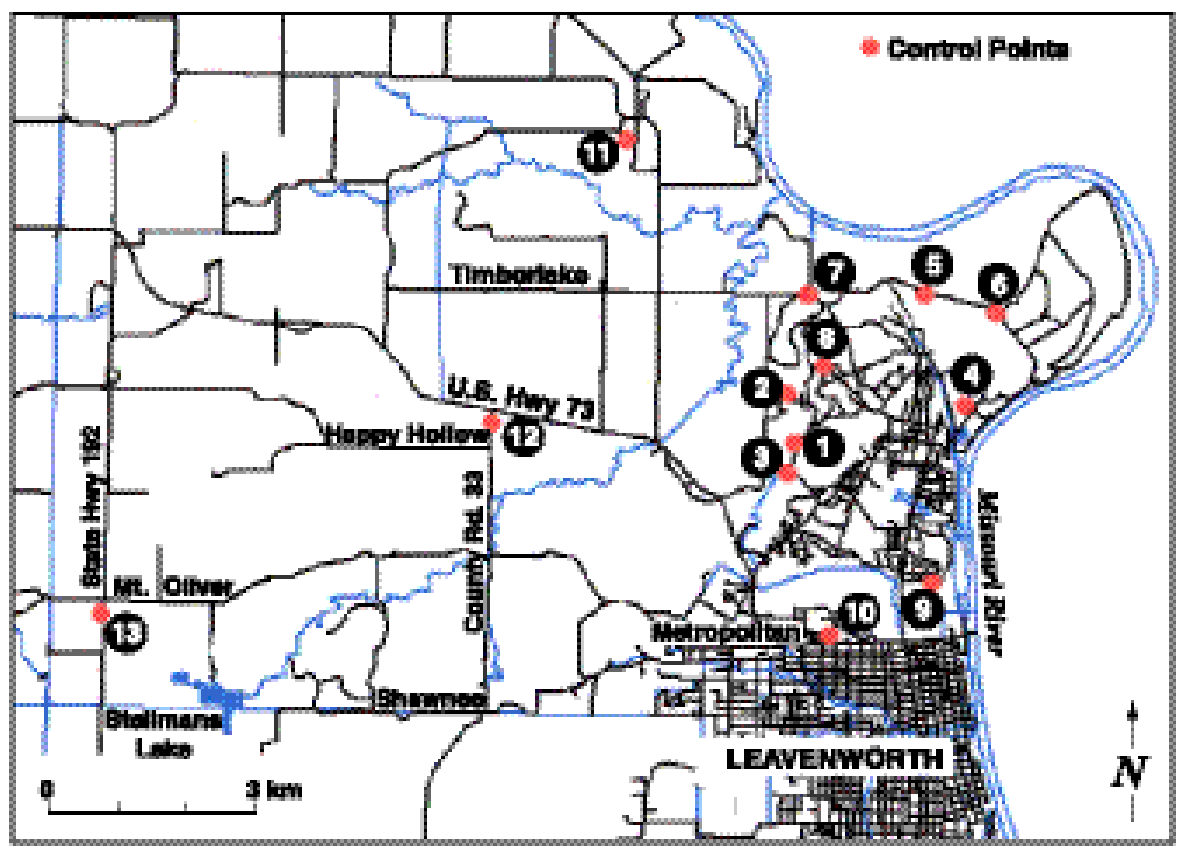

FIGURE 9. Locations of ground control points used for resampling the raw Landsat TM windows. Points 1-10 were collected in the field with differential GPS equipment; points 11-13 were derived from digital topographic maps.

real numbers betweenn -1 and +1 . These values were expanded and converted into byte-binary format (0-255). As table 2 indicates, July 1987 had the highest NDVI value overall, and July 1990 had the lowest (figs. 10, 11). Because the 1989 dataset contained scattered clouds and cloud shadows, the NDVI value was lower than it should have been. To correct this, the clouds and shadows were isolated using unsupervised classification (ISOCLUST module). These features then were removed by creating a cloud-shadow mask, which changed slightly the overall NDVI value for July 1989 from 170.7 to 179.2 and changed its rank from 6 to 5 .

Based on its high NDVI value, the July 1987 scene was selected to represent the best development of forest canopy among the years of data. Unsupervised classification (ISOCLUST module) was carried out on the July 1987 scene to separate forest from other types of land cover. Fifteen clusters were extracted, of which two clusters (1 and 3 ) represented types of forest cover (fig. 12). Field checking revealed close correspondence between the forest boundaries and cluster analysis. The forest clusters were then separated, and adjacent like pixels were joined using the GROUP module (fig. 13). Polygons representing the upland and bottomland study forests were separated to create a mask for each forest. These masks were applied to the NDVI images of each year to remove all portions except for the study forests. This procedure resulted in images that portray NDVI values only for the same areas of upland or bottomland study forests. Once again, the July 1989 dataset required

TABLE 2. Whole-study scene NDVI values for Fort Leavenworth study area. July 1987 has the highest and July 1990 has the lowest values overall. The July 1987 mean NDVI value was set at $100 \%$, and all other percentage values are relative to that.

\begin{tabular}{ccccc}
\hline Year & Mean NDVI & $\begin{array}{c}\text { Standard } \\
\text { Deviation }\end{array}$ & Rank & \\
\hline July 1987 & 201.1 & 28.6 & 100 & 1 \\
July 1988 & 186.9 & 33.2 & 92.9 & 4 \\
July 1989 & 179.2 & 28.7 & 89.1 & 5 \\
July 1990 & 165.7 & 26.0 & 82.4 & 8 \\
July 1991 & 173.4 & 25.0 & 84.0 & 7 \\
July 1992 & 168.8 & 22.9 & 94.7 & 3 \\
July 1994 & 190.4 & 25.0 & 95.8 & 2 \\
\hline
\end{tabular}




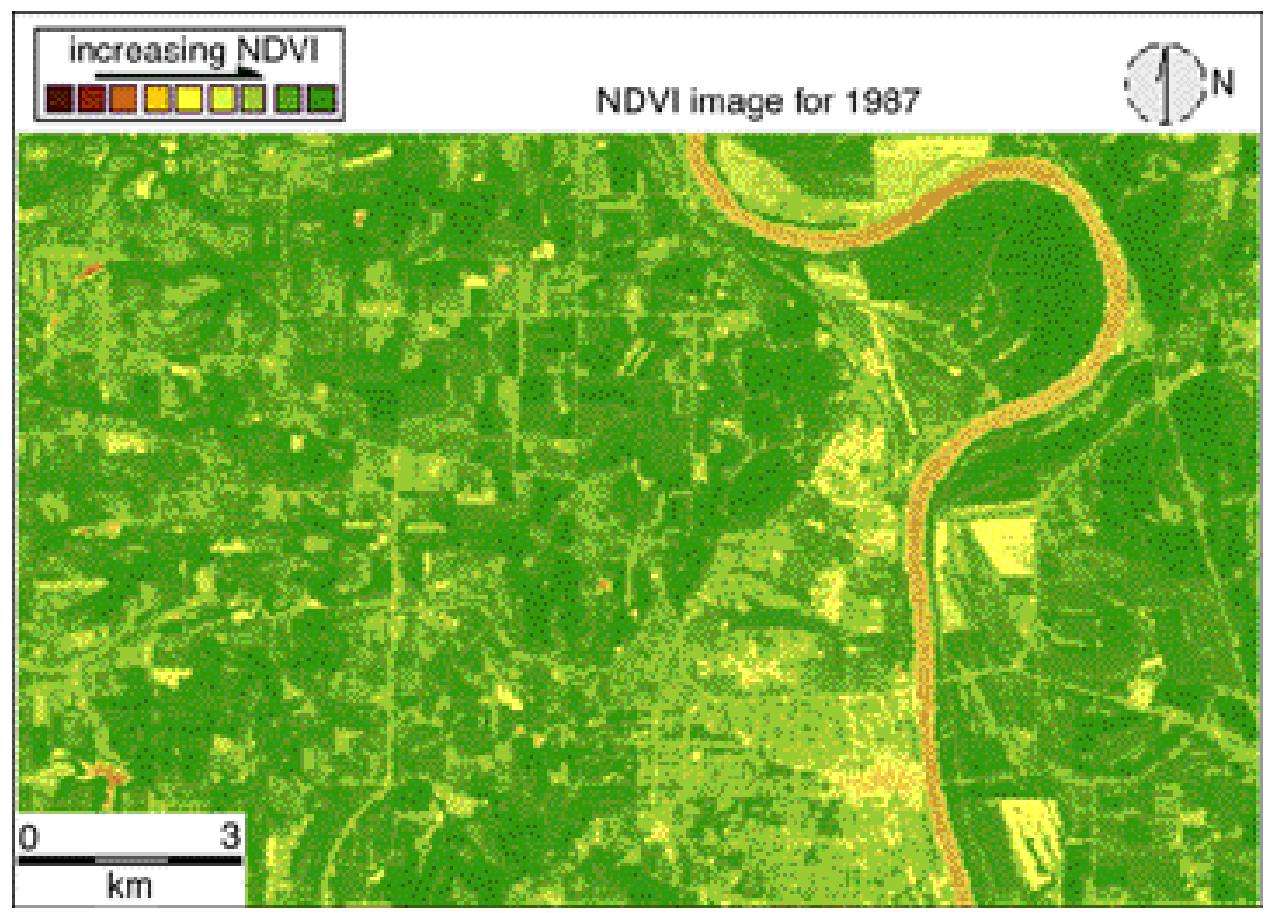

FIGURE 10. NDVI image for July 1987 window of Fort Leavenworth study area. Green shows active vegetation, yellow is unvegetated surfaces, brown depicts water bodies and urban sites. Note contrast in greenness with fig. 11.

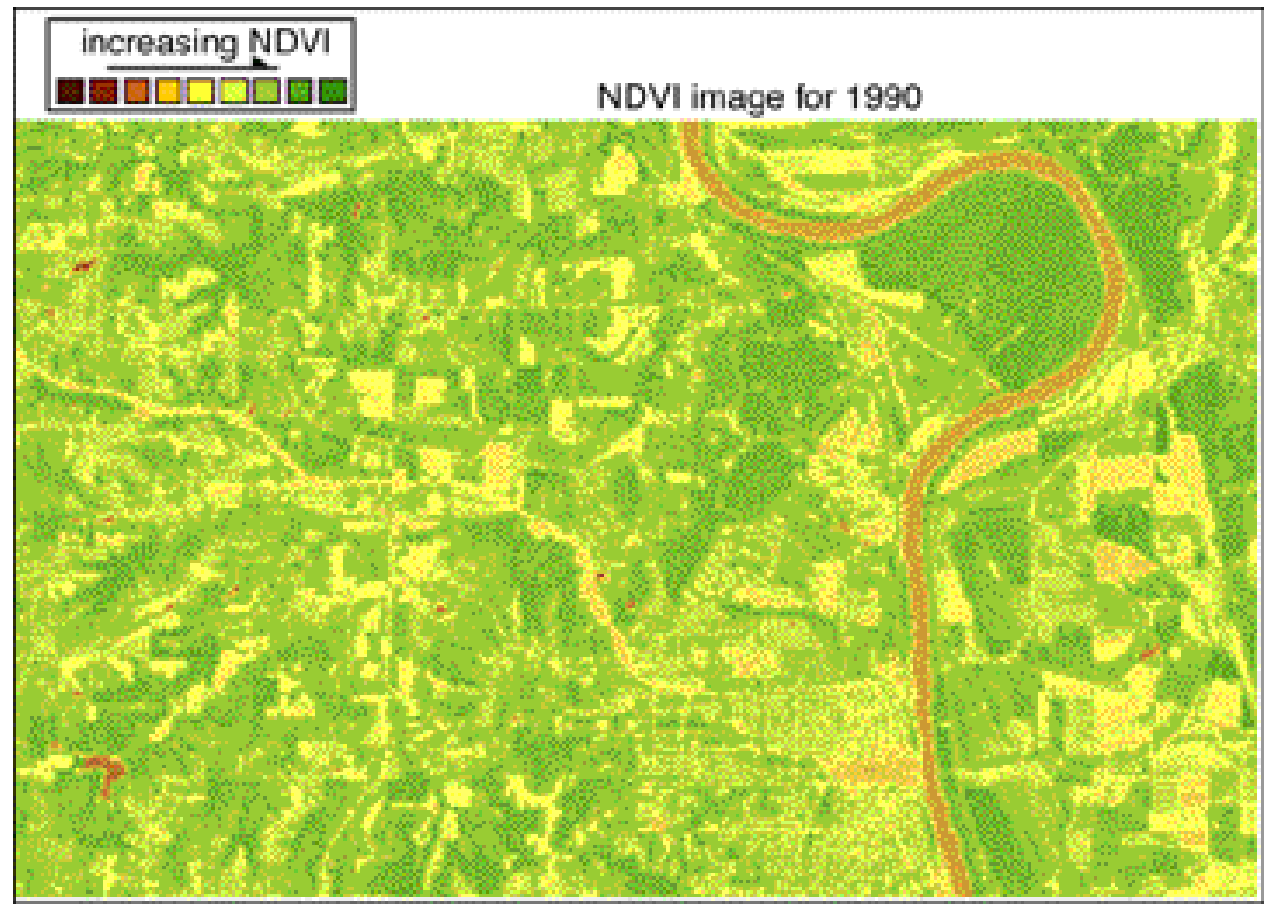

FIGURE 11. NDVI image for July 1990 window of Fort Leavenworth study area. Green shows active vegetation, yellow is unvegetated surfaces, brown depicts water bodies and urban sites. Note contrast in greenness with fig. 10. 


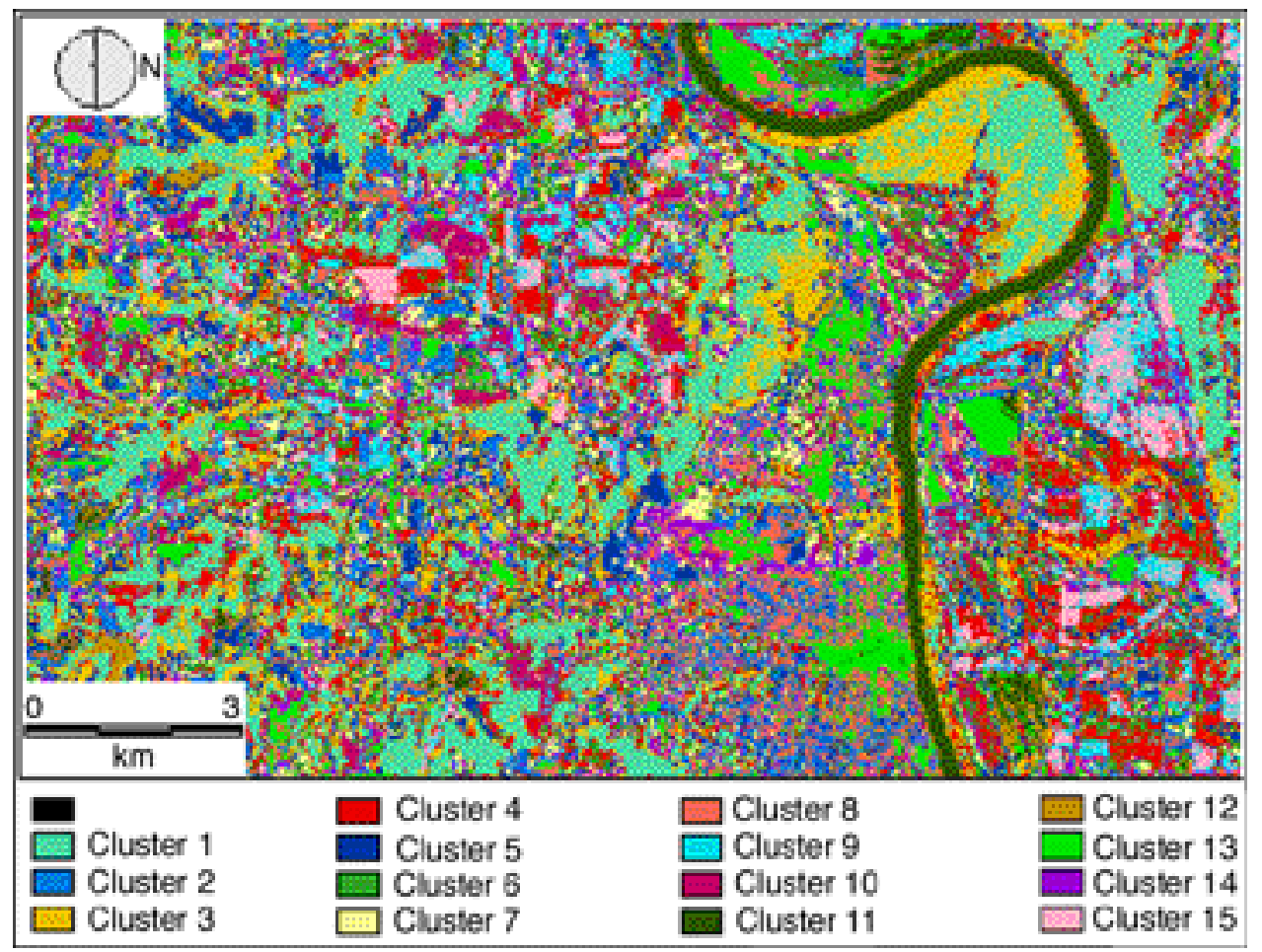

FIGURE 12. Results of unsupervised isocluster classification of July 1987 Landsat TM dataset. Clusters 1 and 3 represent types of forest.

additional processing to remove clouds and cloud shadows from the study-forest areas.

The NDVI images for upland and bottomland study forests were evaluated with principal-component analysis and image-differencing techniques. In IDRISI, the Time Series Analysis module performs principal-component analysis, which is a statistical technique for separating a multivariate dataset into uncorrelated linear combinations or components. Each component has little variance, but together they represent all the data in the original dataset. If there is significant intercorrelation within the data, the first few components account for a large part of the variance. Cloud cover and shadows in the July 1989 dataset created a problem of pixel contamination, so this dataset was omitted from the principal-component analysis. Cloud cover also affected the upland study forest for July 1992, and it was omitted as well.

Image differencing is used to detect spectral changes between two images, based on subtracting the value of cells in one image from corresponding cell values in another image. The result is an image that contains the difference values, which may be positive, zero, or negative. A histogram of difference values typically follows a symmetrical, normal distribution (Eastman et al., 1995). To determine cells of real change, a threshold is set; values beyond this threshold are considered to represent extraordinary change. Image differencing was performed for NVDI image-pairs from both upland and bottomland forests; these pairs were selected to represent change throughout the period of study: 1988-1987, 1990-
1988, 1994-1991, 1997-1994, and 1997-1987. The threshold value was set in each case at two standard deviations from the mean NDVI difference.

A band 5:4 ratio image was prepared for each whole July dataset to obtain the moisture stress index (MSI). (Clouds and cloud shadows were removed from the July 1989 image as noted above.) Ratios for the study forests were then extracted using the upland and bottomland forest masks derived from the July 1987 image. The results are positive real numbers in the range 0.5 to 0.9 , as band 4 is generally somewhat brighter than band 5 for active vegetation. Preliminary results revealed a gradual, long-term decrease in band 5:4 ratios for both upland and bottomland study forests (fig. 14). Linear-regression analysis was used to remove the long-term downward trend from the band 5:4 ratio values. Residual values obtained from this process represent departures (positive or negative) from the trend and were used for further analysis and interpretation.

\section{Climatic Data and Tree-ring Analysis}

Climatic data for 1986 to 1997 were obtained for northeastern Kansas from the National Climatic Data Center (NCDC, 1999). Average values for temperature, precipitation, and Palmer Drought Severity Index (PDSI) were calculated for the 12-month period from July to June, preceding the July image capture date each year. For example, the average values for 1987 include the period July 1986 to June 1987. In this way, the average 


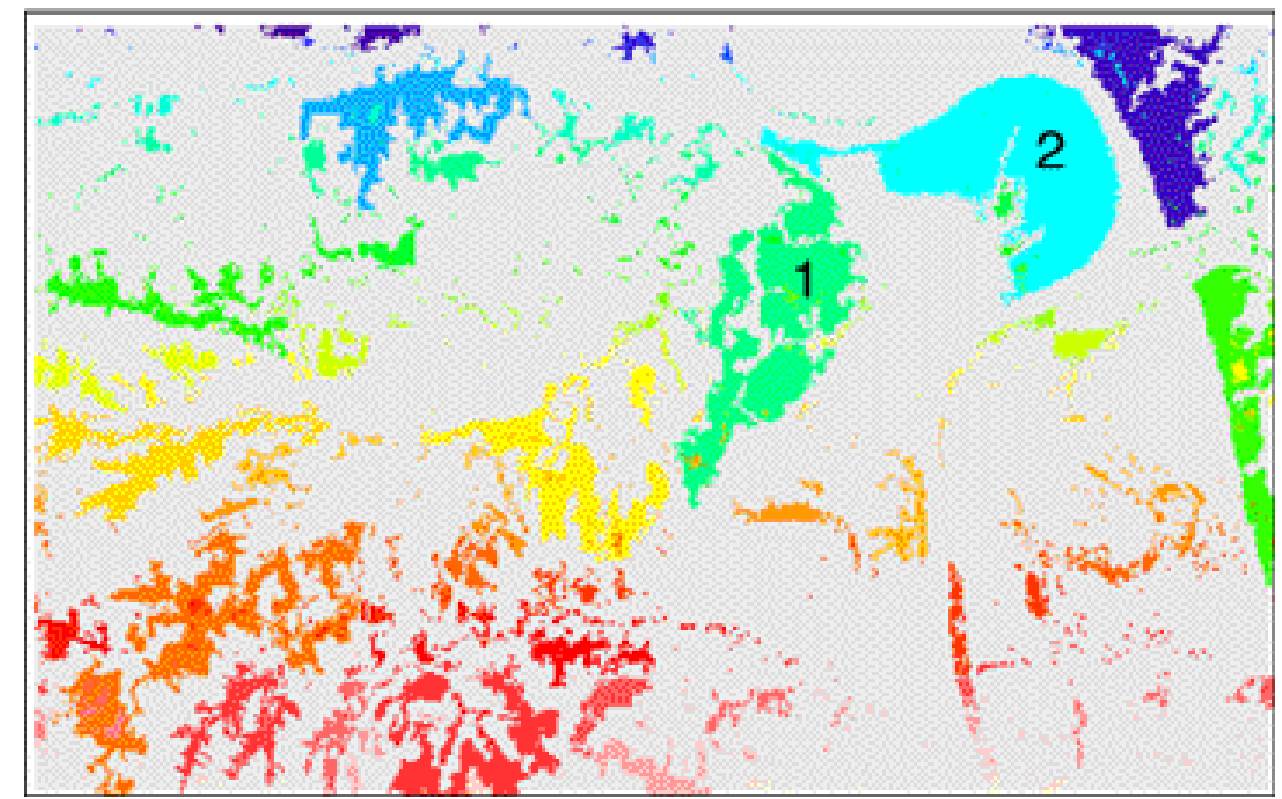

Figure 13. Forest cluster pixels grouped into polygons of contiguous pixels. Polygon 1 represents the upland study forest; polygon 2 is the bottomland study forest.

values indicate yearly climatic conditions leading up to the time of image capture. In addition to the 1986-1997 climatic data, older climatic data were applied to interpretation of the tree record (Nang, 1998). Similarly, field observations during the course of a winter 2000 drought were applied to the interpretation of Landsat TM imagery for the 1988-1989 drought.

Results of tree-ring analysis were obtained from Nang (1998), who collected two tree-ring cores from each of 15 oak trees in the upland forest in 1997. Sampled tree species included red oak (Quercus rubra), black oak ( $Q$. velutina Lam.), post oak (Q. stellata Wang), white oak ( $Q$. alba L.) and chestnut oak (Q. muehlenbergii Engelm.).

Because the chestnut oak proved to have indistinct annual rings that were difficult to measure, it was not included in the analysis. Ring widths were measured for the last 30 years (1968-1997). The long-term decline in ring width, a typical tree-growth phenomenon, was removed by linearregression analysis. The resulting residual values reflect deviations from the long-term growth trend. The residual

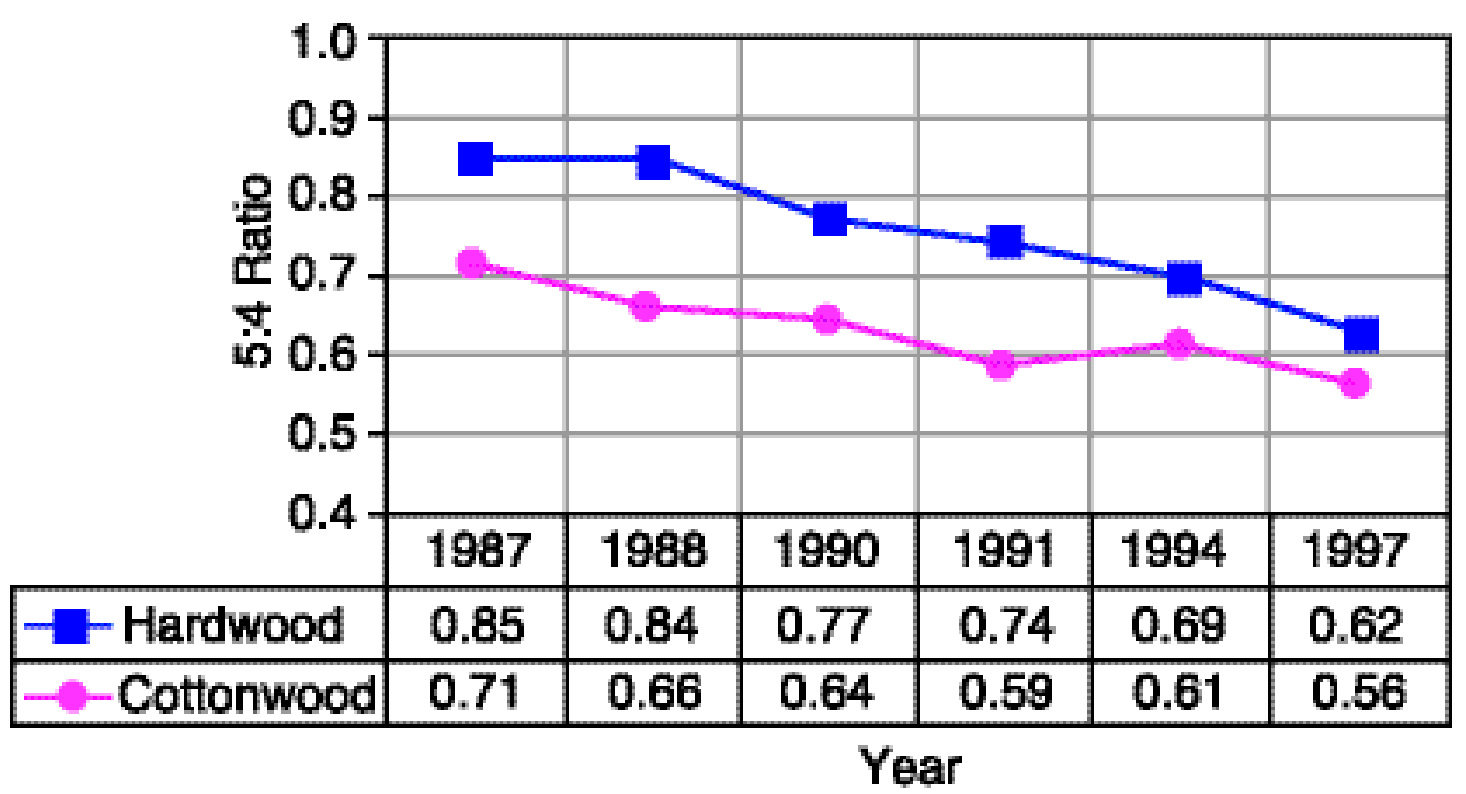

Figure 14. TM band 5:4 ratios for upland (hardwood) and bottomland (cottonwood) study forests at Fort Leavenworth, Kansas.

Both forests display gradual decreases in band 5:4 ratios, though the hardwood forest ratios are consistently higher. 


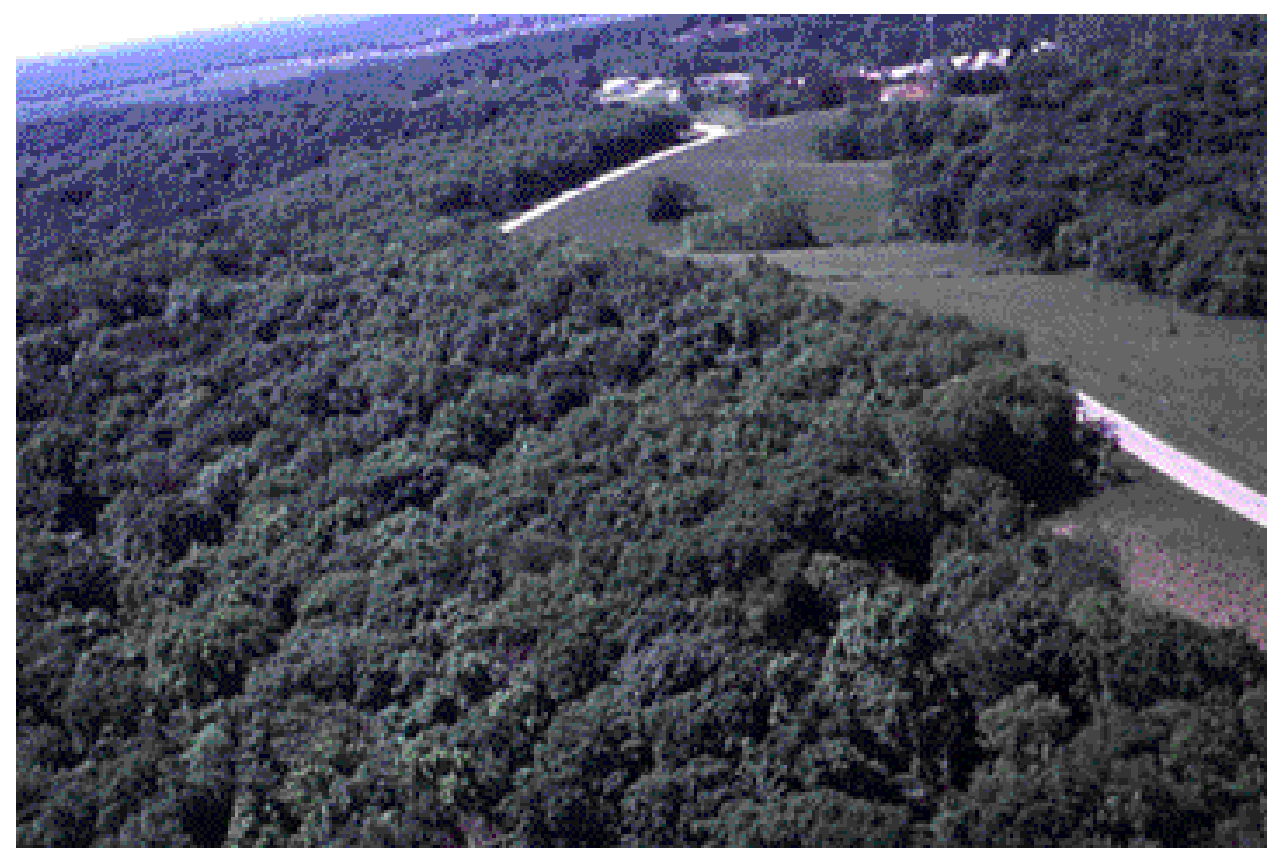

FIGURE 15. Normal-color kite aerial photograph of the upland study forest, Fort Leavenworth, Kansas, May 2000. Oblique view toward the south shows a fully developed forest canopy. Compare with fig. 16.

data are reported as positive or negative values in tenths of millimeters. Annual residual values were averaged for all samples of red, black, white and post oak, the species that proved to have the most consistent records.

\section{Kite Aerial Photography}

Kite aerial photography (KAP) involves the use of large kites to lift camera rigs 50-150 m (160-500 ft) above the ground. Various types of radio-controlled, single- and dual-camera systems may be employed to acquire images in visible and near-infrared portions of the spectrum (Aber et al., 1999, 2001). Beginning in 1997, KAP was employed yearly to document canopy conditions in the upland forest; the bottomland forest was photographed beginning in 1998. KAP was conducted mainly in the spring (April-June) to better understand forest greenup and to evaluate canopy structure, with and

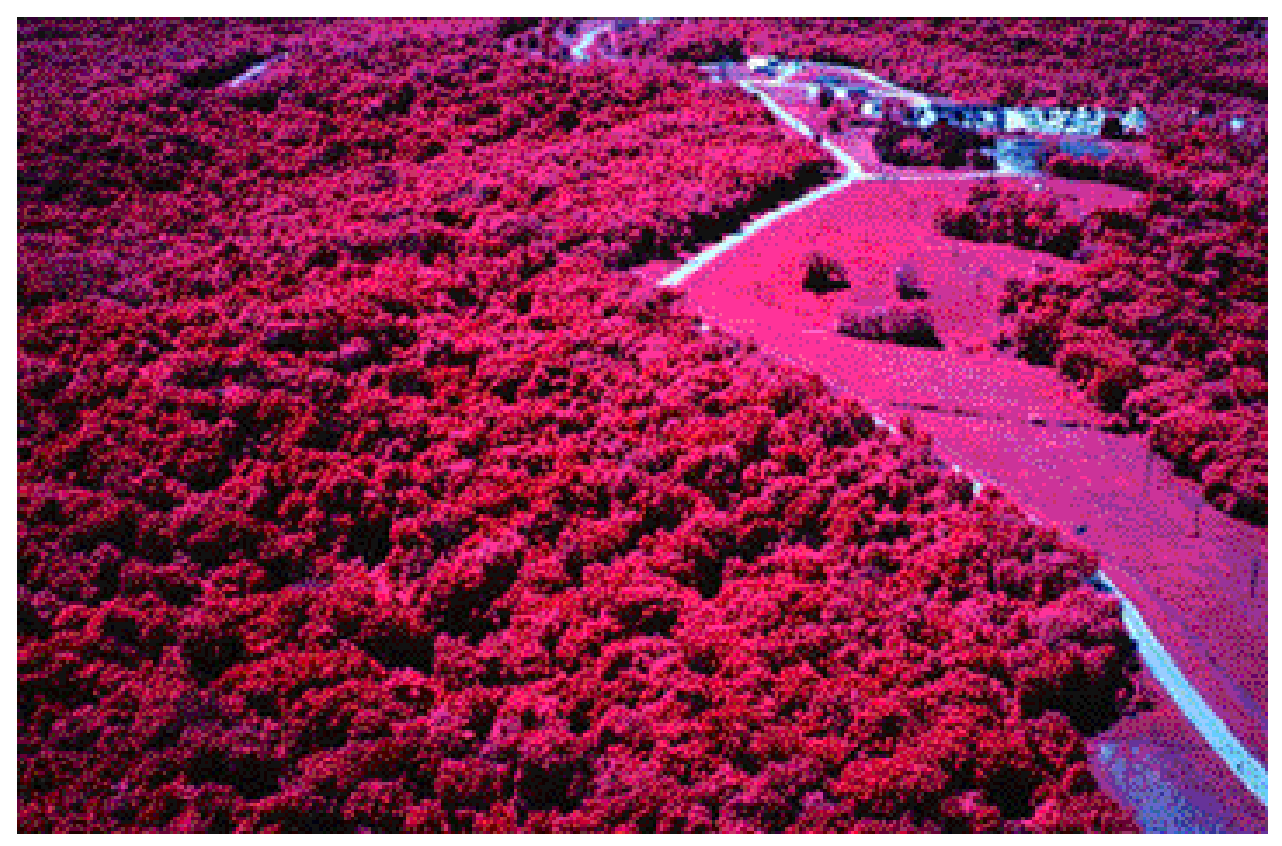

FIGURE 16. Color-infrared kite aerial photograph of the upland study forest, Fort Leavenworth, Kansas, May 2000. Active vegetation appears in red and pink colors. Compare with fig. 15. 


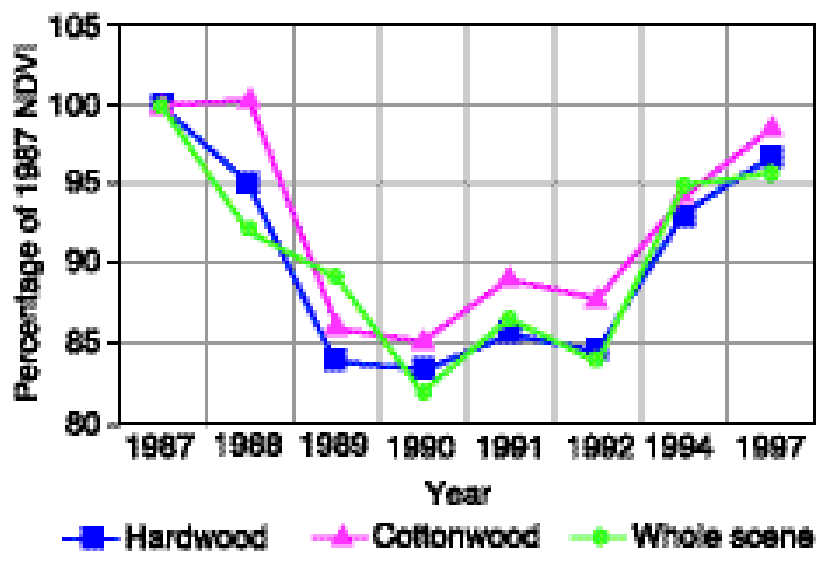

FIGURE 17. Relative NDVI values for upland (hardwood), bottomland (cottonwood), and whole-scene study areas, based on July 1987 as $100 \%$. The lowest values in all cases are for July 1990. The bottomland forest shows an anomalous increase in July 1988.

without leaves. Photographs were taken in vertical and oblique modes using color-visible and color-infrared diapositive (slide) film (figs. 15, 16). Selected photographs were scanned into digital format, with pixel resolution ranging from $10 \mathrm{~cm}$ to $20 \mathrm{~cm}$ (4 in to 8 in). The clarity of detail in such images allowed interpretation of canopy structure at submeter resolution.

\section{Results}

\section{Landsat TM Results}

Normalized Difference Vegetation Index (NDVI) values for upland and bottomland forests are presented in table 3 . The wide range in values suggests that saturation of NDVI did not take place for the study forests. The relative percentages for upland forest, bottomland forest, and whole-study scene NDVI values are given in fig. 17. Percentage changes are mostly parallel, and all categories

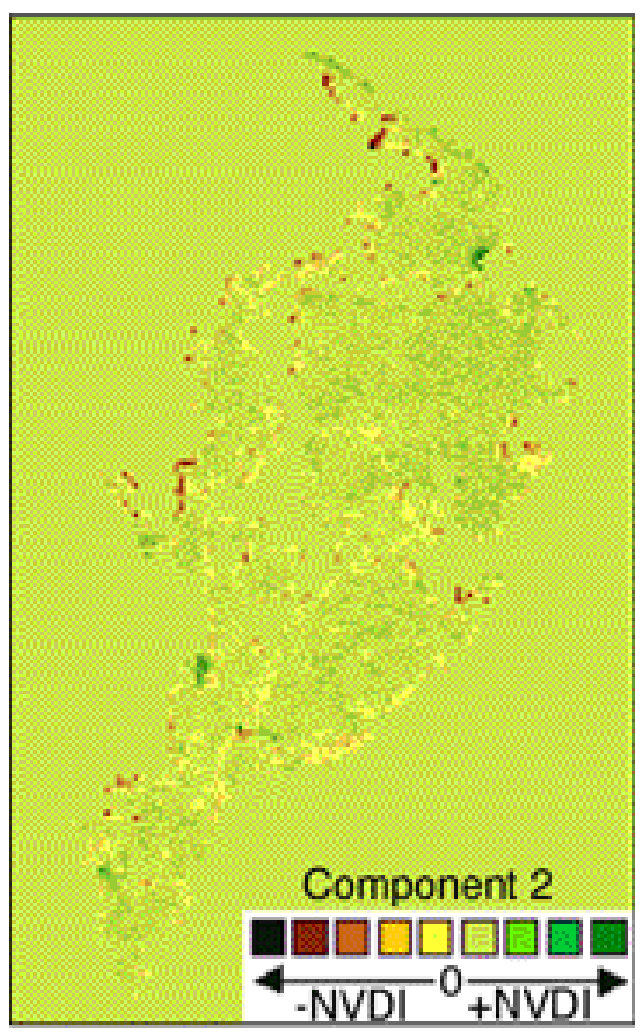

FIGURE 18. Upland forest image showing component two of the NDVI principal-component analysis. Positive values indicate an increase in vegetation cover, and negative values show loss of vegetation cover. Most change (loss) is located on the outer perimeter and along roads and other clearings in the disjunct forest cover.

display minimum NDVI values in 1990. Contrary to the consistent overall trend, the bottomland forest shows a small increase in July 1988, and the NDVI percentages for the bottomland forest are slightly higher throughout in relation to the upland forest.

Principal-component analysis was carried out on sixscene datasets for the upland and bottomland study forests (table 4). These results show that more than $99.9 \%$

TABLE 3. Mean NDVI, standard deviation, and NDVI percentage values for upland (hardwood) and bottomland (cottonwood) forests. Compare with whole-study scene NDVI values (Table 2).

\begin{tabular}{|c|c|c|c|c|c|c|}
\hline Year & $\begin{array}{l}\text { Hardwood } \\
\text { mean NDVI }\end{array}$ & $\begin{array}{c}\text { Hardwood } \\
\text { standard deviation }\end{array}$ & $\begin{array}{l}\text { Hardwood } \\
\% \text { NDVI }\end{array}$ & $\begin{array}{l}\text { Cottonwood } \\
\text { mean NDVI }\end{array}$ & $\begin{array}{c}\text { Cottonwood } \\
\text { standard deviation }\end{array}$ & $\begin{array}{c}\text { Cottonwood } \\
\% \text { NDVI }\end{array}$ \\
\hline 1987 & 227.7 & 4.6 & 100 & 223.7 & 4.8 & 100 \\
\hline 1988 & 216.4 & 12.2 & 95.0 & 224.3 & 6.2 & 100.3 \\
\hline 1989 & 191.2 & 6.4 & 83.9 & 192.8 & 7.8 & 86.2 \\
\hline 1990 & 189.8 & 7.1 & 83.3 & 190.7 & 8.3 & 85.3 \\
\hline 1991 & 195.1 & 7.4 & 85.7 & 199.2 & 6.0 & 89.1 \\
\hline 1992 & 192.5 & 9.8 & 84.5 & 196.4 & 4.3 & 87.8 \\
\hline 1994 & 211.7 & 9.1 & 93.0 & 211.0 & 8.7 & 94.3 \\
\hline 1997 & 220.0 & 7.4 & 96.6 & 220.4 & 4.8 & 98.5 \\
\hline
\end{tabular}




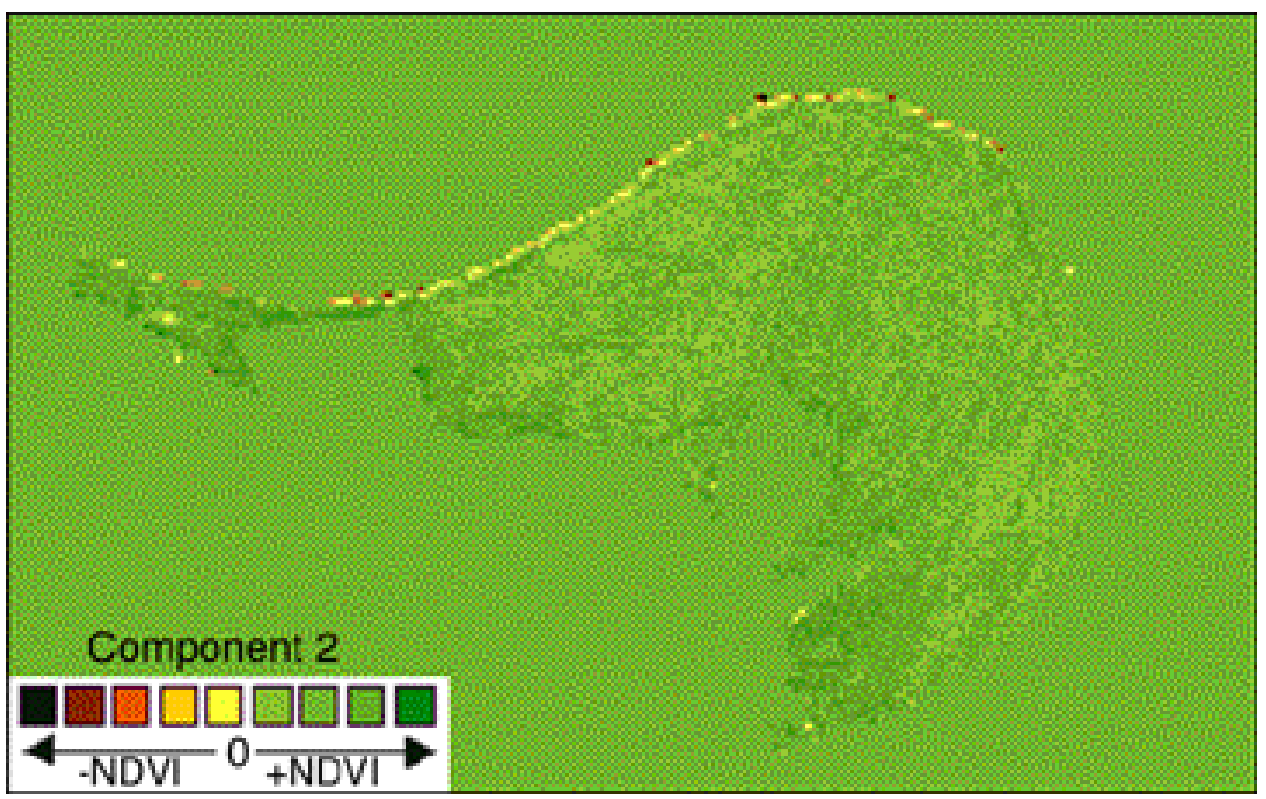

FIGURE 19. Bottomland forest image showing component two of the NDVI principal component analysis. Positive values indicate an increase in vegetation cover, and negative values show loss of vegetation cover. Most change (loss) is located on the northern perimeter of the forest along the Missouri River channel.

of the variations in both study forests are accounted for by component one. This suggests that the datasets for all years are highly correlated, and this correlation is similar in nearly all respects to yearly NDVI values. Small variations are associated with components $2-6$.

Component 2 represents about $0.02-0.03 \%$ of the variance. This component is associated mostly with zones that are 2-3 pixels wide on edges and boundaries of both upland and bottomland forests (figs. 18, 19). The higherorder components (3-6) display even smaller values (about $0.01 \%$ or less). Such small values could be the results of slight differences in image registration or other noise effects; they are not considered significant for further interpretation.

The results of image differencing for both study forests (table 5) are consistent with the trends of NDVI values and results of principal-component analysis. The most drastic declines for both forests took place during the 1988 to 1990 period (1990-1988). Once again, the bottomland study forest displays a slight increase for the period 1987 to 1988 (1988-1987), in contrast to decline for the upland study forest. The best recoveries were during the interval 1991 to 1994 (1994-1991), followed by the period 1994 to 1997 (1997-1994). The overall change from 1987 to 1997 (1997-1987) is down slightly for both study forests. NDVI difference images reveal that most changes took place around the margins of the study forests (figs. 20 and 21).

Trend lines and residual values for TM band 5:4 ratios are presented in figs. 22 and 23 for the study forests. The trend lines display near-parallel declines with upland forest values consistently higher than bottomland forest values. Yearly increases in residual values represent leaves with lower moisture content, and decreases indicate more leaf moisture. The residual values change in similar fashion for both forests for each year except 1988, when the forests experienced opposite changes: the upland forest increased, while the bottomland forest decreased. The opposite changes in TM band 5:4 residual values for July 1988 correspond to similar anomalies in NDVI values. Both study forests experienced lowest leaf moisture (highest 5:4 residuals) in 1989 and highest leaf moisture (lowest 5:4 residuals) in 1992.

\section{Climatic Data and Tree-ring Results}

Table 6 presents data for climatic factors and average residual tree-ring widths for the study period 1987-1997. In 1988 and 1989, precipitation was far below normal, and the Palmer Drought Severity Index (PDSI) reached its

TABLE 4. Percent variances for components 1-6 of six-scene datasets for upland and bottomland study forests, Fort Leavenworth, Kansas. Datasets include July forest masks for 1987, 1988, 1990, 1991, 1994, and 1997.

\begin{tabular}{lcccccc}
\hline Study forest & Component 1 & Component 2 & Component 3 & Component 4 & Component 5 & Component 6 \\
\hline Upland & 99.93196 & 0.02697 & 0.01378 & 0.01113 & 0.00914 & 0.00703 \\
Bottomland & 99.94922 & 0.01918 & 0.01312 & 0.00747 & 0.00648 & 0.00453 \\
\hline
\end{tabular}


TABLE 5. Image differencing results for upland (hardwood) and bottomland (cottonwood) study forests, Fort Leavenworth, Kansas. Greatest declines were for 1990-1988, and best improvements for 1994-1991. Compare with fig. 17.

\begin{tabular}{ccccc}
\hline Years & $\begin{array}{c}\text { Hardwood NDVI } \\
\text { difference mean }\end{array}$ & $\begin{array}{c}\text { Hardwood } \\
\text { standard deviation }\end{array}$ & $\begin{array}{c}\text { Cottonwood NDVI } \\
\text { difference mean }\end{array}$ & $\begin{array}{c}\text { Cottowood } \\
\text { standard deviation }\end{array}$ \\
\hline $1988-1987$ & -6.3 & 11.0 & 0.6 & 5.6 \\
$1990-1988$ & -26.6 & 10.5 & -33.5 & 8.0 \\
$1994-1991$ & 16.6 & 7.1 & 11.7 & 7.2 \\
$1997-1994$ & 8.4 & 6.8 & 9.4 & 7.7 \\
$1997-1987$ & -2.7 & 7.3 & -3.3 & 5.3 \\
\hline
\end{tabular}

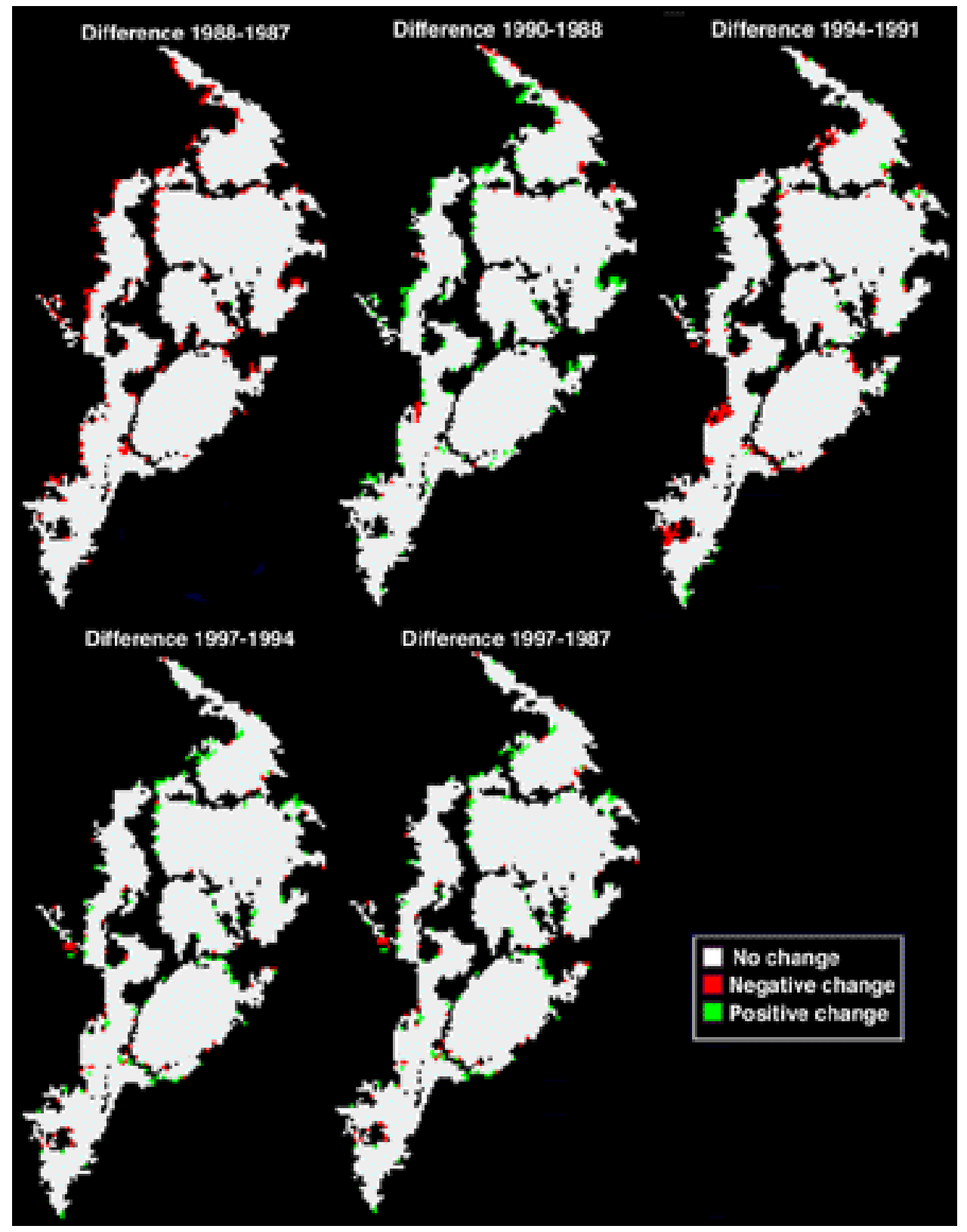

FIGURE 20. NDVI difference images for year-pairs of the upland study forest, Fort Leavenworth, Kansas. Most changes, both positive (green) and negative (red), are situated around the forest margin. 

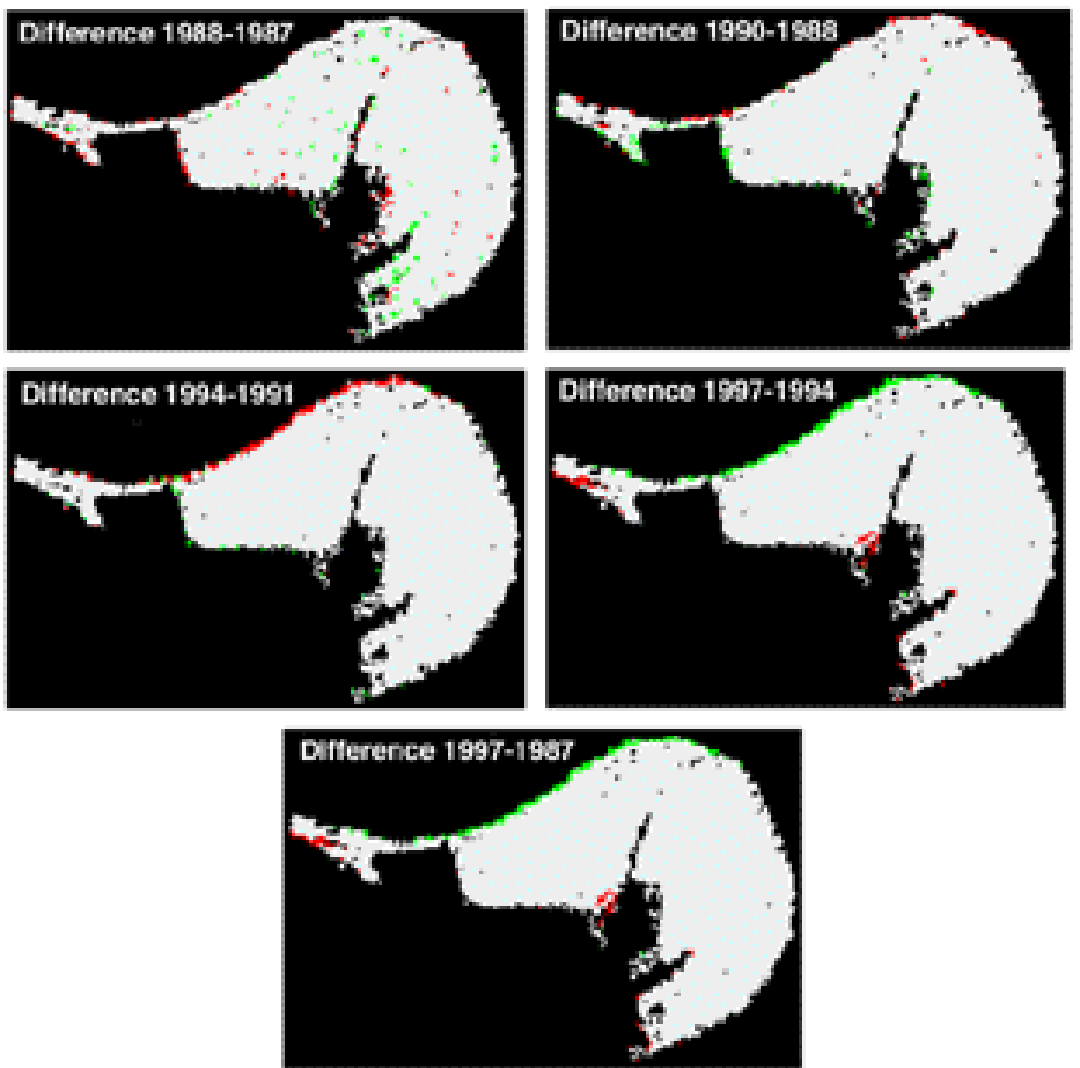

FIGURE 21. NDVI difference images for year-pairs of the bottomland study forest, Fort Leavenworth, Kansas. Most changes, both positive (green) and negative (red), are situated around the forest margin.

lowest value in 1989. In 1991 and 1992, precipitation and PDSI values were also low. Tree-ring widths had the lowest (most negative) residual values in 1988, 1989, and 1991, during the two drought periods. In contrast, during 1987 and 1993, precipitation was over $100 \mathrm{~cm}$ (39 in) and PDSI values were greater than 3 . The highest value for residual tree-ring width was in 1987, with high values also in 1990 and 1996. As fig. 24 illustrates, average precipitation, PDSI, and tree-ring residual width were generally in agreement; however, average temperature followed a different trend, generally opposite to precipitation and PDSI.

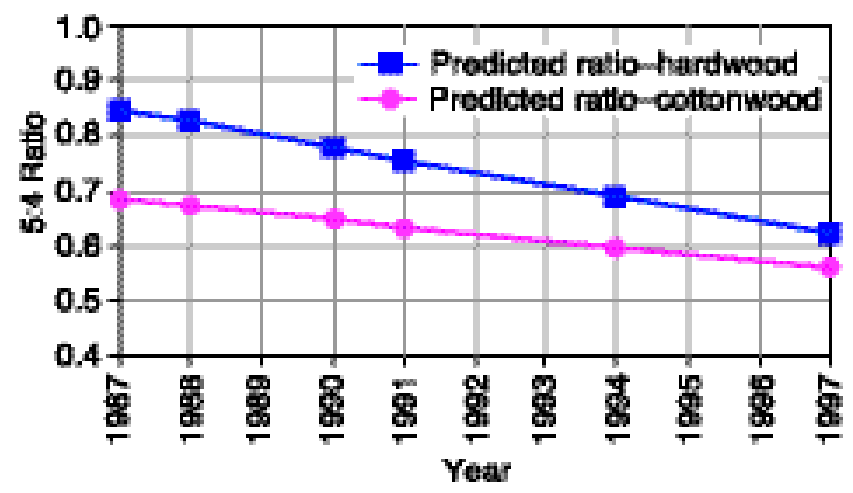

FIGURE 22. Linear trends for TM band 5:4 ratios for upland (hardwood) and bottomland (cottonwood) study forests at Fort Leavenworth, Kansas. Both forests display negative trends, though the hardwood forest ratios are consistently higher.

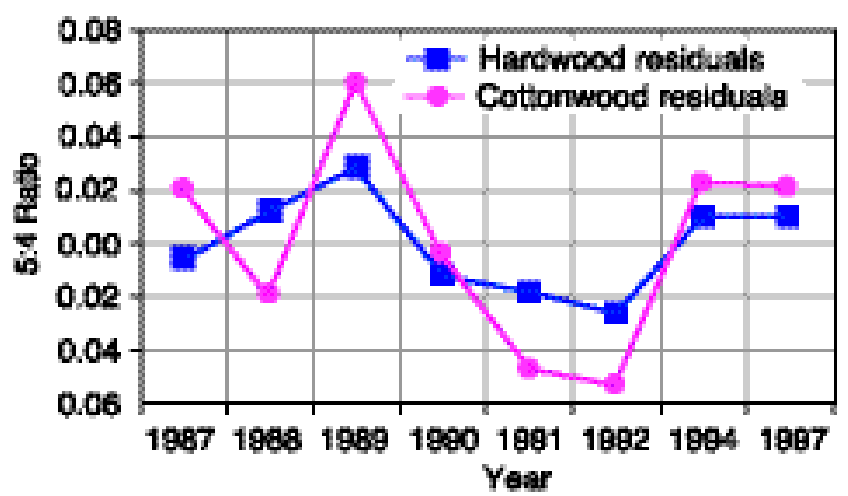

FIGURE 23. Residual values for TM band 5:4 ratios for upland (hardwood) and bottomland (cottonwood) study forests at Fort Leavenworth, Kansas. for 1988, residual values for both forests fluctuate in similar ways. 
TABLE 6. Climatic and tree-ring data for Fort Leavenworth, Kansas, 1987-1997. Based on data from the National Climatic Data Center (NCDC, 1999) and Nang (1998). Mean annual 12-month periods are from July of the preceding year to June of the reported year. As noted in the text, residual tree-ring widths indicate deviations from long-term growth trends and are given in tenths of millimeters. PDSI $=$ Palmer Drought Severity Index.

\begin{tabular}{ccccc}
\hline Year & $\begin{array}{c}\text { Mean annual } \\
\text { precipitation }(\mathrm{cm})\end{array}$ & $\begin{array}{c}\text { Mean annual } \\
\text { temperature }\left({ }^{\circ} \mathrm{C}\right)\end{array}$ & $\begin{array}{c}\text { Mean annual } \\
\text { PDSI }\end{array}$ & $\begin{array}{c}\text { Annual residual } \\
\text { tree-ring width }(0.1 \mathrm{~mm})\end{array}$ \\
\hline 1987 & 100.8 & 13.0 & 3.46 & 3.64 \\
1988 & 58.0 & 12.2 & -0.28 & -6.42 \\
1989 & 43.2 & 12.2 & -4.27 & -2.22 \\
1990 & 84.8 & 11.9 & 0.34 & 2.94 \\
1991 & 64.7 & 13.0 & -0.56 & -2.59 \\
1992 & 59.0 & 12.7 & -0.58 & 0.67 \\
1993 & 104.2 & 10.5 & 3.14 & 0.85 \\
1994 & 93.1 & 11.8 & 1.69 & -1.63 \\
1995 & 81.8 & 11.8 & -0.30 & -0.41 \\
1996 & 72.9 & 11.5 & 0.39 & 2.11 \\
1997 & 72.9 & 11.0 & 1.91 & - \\
\hline
\end{tabular}

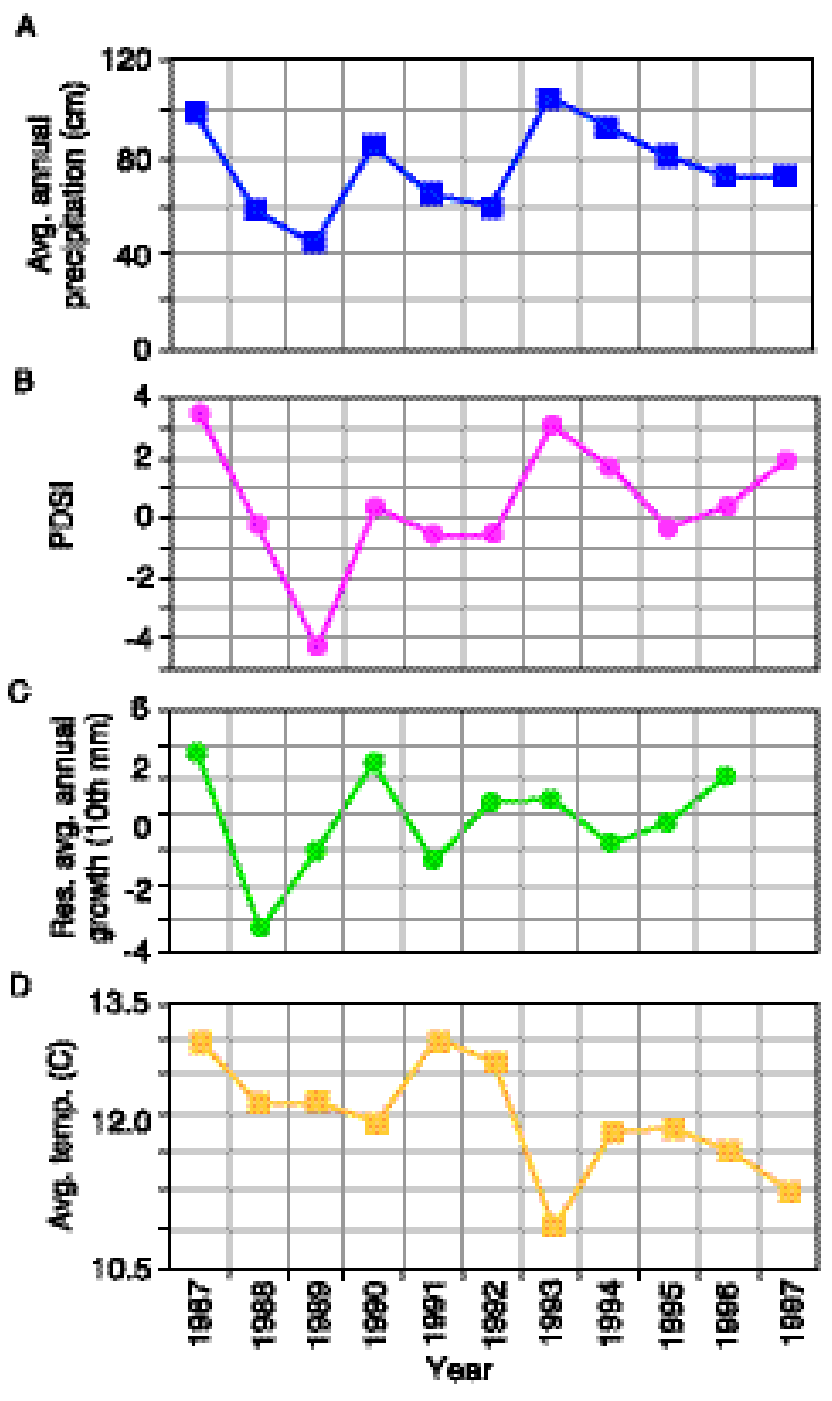

FIGURE 24. Average annual precipitation (A), PDSI (B), residual tree-ring width (C), and average temperature (D) for the study period 1987 to 1997, Fort Leavenworth, Kansas.

\section{Kite Aerial Photography}

Photographs, both single-frame and stereo-pair modes, were taken with KAP repeatedly in normal color over the upland forest. Color-infrared images were taken in April and May 2000 and in June 2001. These various views reveal that the forest canopy is quite rough at a resolution of 1-10 m (3-33 ft) (fig. 25). Taller trees, mainly white oaks, extend several meters above neighboring trees, which creates numerous shadows in the canopy, when viewed from above. Vertical and oblique views reveal the upland forest has a closed canopy, except where openings exist for roads, trails, water tanks, or other human structures.

In April 2000, KAP was used to obtain images of the bottomland forest a few days after the adjacent grassland was subjected to a controlled burn. The same site was rephotographed one month later in May, and again in June 2001. The fire penetrated some distance into the forest understory, as shown on the April image (fig. 26). This burn took place at a time when the cottonwood trees had green flowers, but had not yet leafed out. The May images reveal that trees along the forest margin were injured by the fire. Some trees were completely bare, and others had leaves only in the upper portions or on one side. Trees within the main body of forest, however, were not affected by the fire.

\section{Interpretation and Discussion}

Climatic factors (precipitation and PDSI) and residual tree-ring widths display a close relationship, such that the initiation of drought (1988 and 1991) results in major reduction of tree-ring growth (see fig. 24). In contrast, the initiation of drought had minimal effect on Landsat 

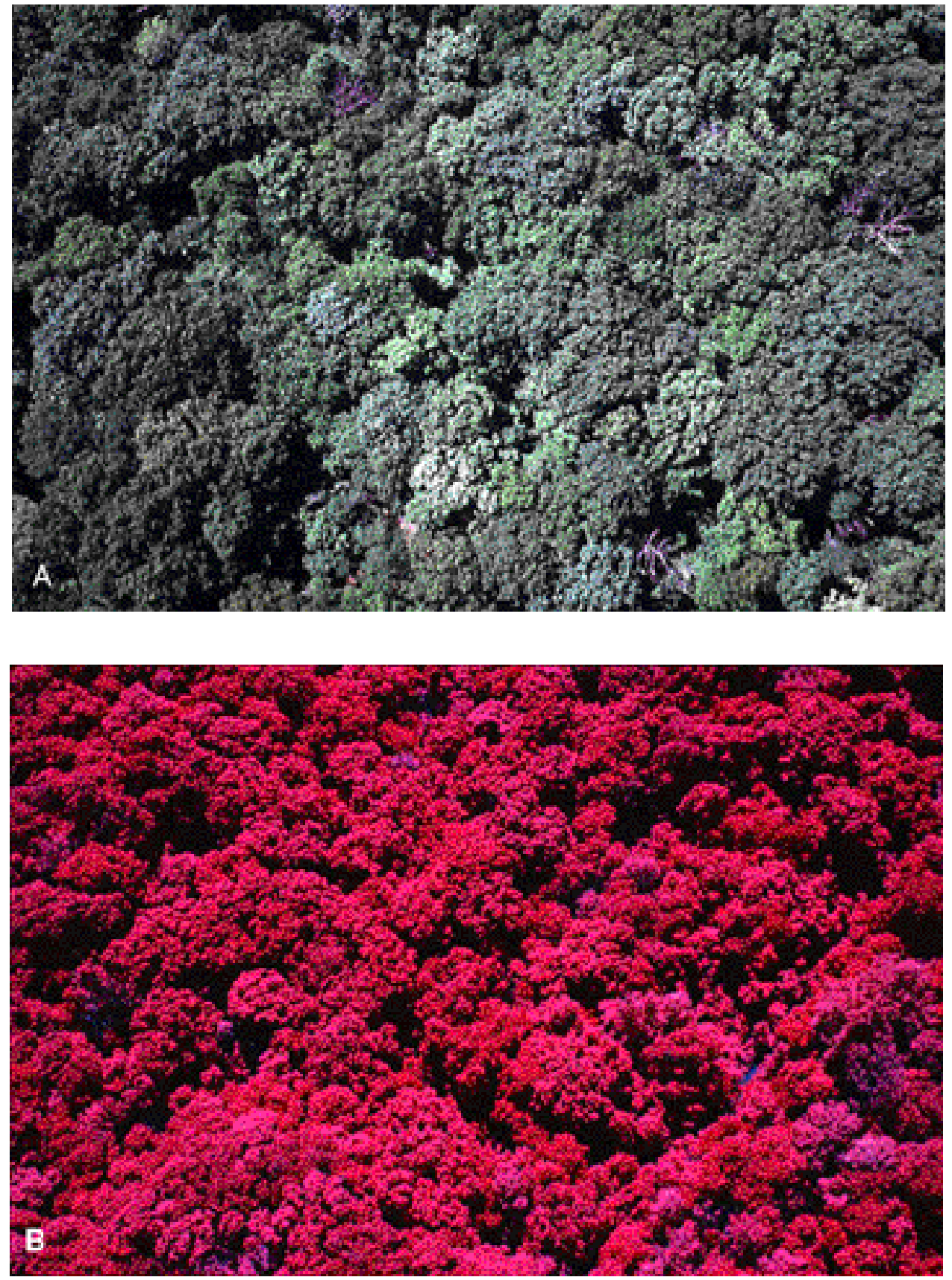

FIGURE 25. Normal-color (A) and color-infrared (B) near-vertical views of the upland study forest, May 2000. Notice the rough canopy surface in which many shadows are present. The canopy completely covers the forest floor.

NDVI values for the study forests (see fig. 17). In fact, the July 1988 bottomland forest experienced a slight increase in its NDVI value compared to 1987 . NDVI values reached their minima in 1990 for all categories of analysis-whole-study scene, upland forest, and bottomland forest. NDVI values declined from 1989 to 1990, even though precipitation and tree-ring growth increased substantially in 1990. A similar, but smaller decline in NDVI values occurred in 1992, a year after the beginning of drought in 1991. Again, this change in NDVI was out of phase with tree-ring growth.
Landsat NDVI values for northeastern Kansas do not reflect climatic conditions for the current growing season nor for the preceding 12-month period. Instead, changes in NDVI values of forests lag one to two years behind significant climatic events. Furthermore, changes in NDVI values take place a year after variations in tree-ring growth for the upland forest. These results are consistent with earlier preliminary findings for the study area (Aber et al., 1998). Similar NDVI lag effects have been noted in other forest studies in Kansas (Wang et al., 2001) and in East Africa (Davenport and Nicholson, 1990). Thus, 


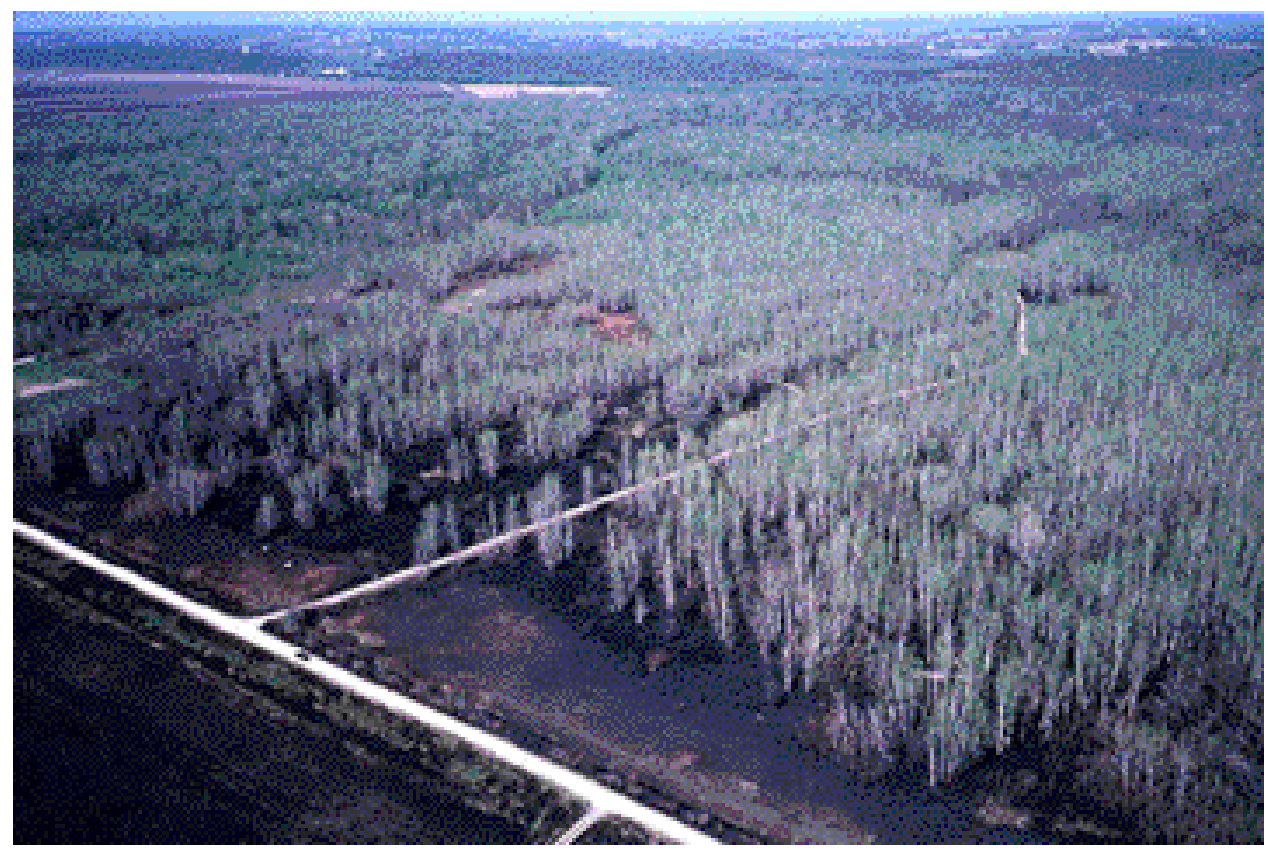

FIGURE 26. Normal-color, oblique view over the bottomland study forest, April 2000. The adjacent grassland was burned intentionally a few days before this picture, and the fire penetrated the forest understory some distance. At the time of this image, cottonwood trees had green flowers, but had not yet leafed out.

satellite-derived NDVI values should be used cautiously when interpreting impacts of current climate on growth of deciduous forest in similar settings. The NDVI values most likely represent climatic events of the previous one or two years.

Landsat NDVI values are a reflection of the forest canopy, namely leaf area index (LAI). The growth of leaves in deciduous forest is based on food stored in tree limbs and twigs. The amount of food available for leaf growth in the spring is a function of favorable or unfavorable climatic conditions of the previous growing season. Thus, the forest canopy in a given year is a reflection of antecedent climatic events. In contrast, growth of wood in the body of the tree depends primarily on moisture and nutrients available to the tree roots (Fritts, 1976). This involves a combination of shallow soil moisture and deeper ground water. The former often depends on recent precipitation events during the winter and early portion of the growing season, whereas the latter responds to multi-year climatic fluctuations. Thus, tree-ring growth may have a rather complicated relationship to short- and long-term climatic events.

The upland study forest, for which tree-ring data were collected, depends entirely on soil moisture to support tree growth. Moderate to steep slopes promote rapid runoff of precipitation, and ground water is far below the zone of tree roots. In this situation, growth of tree rings in oak species is sensitive to climatic events, especially drought episodes (Fritts, 1976). It is not surprising to find close correlation between residual tree-ring width, precipitation, and PDSI on an annual basis. The bottomland study forest, in contrast, depends almost entirely on ground water, which lies only a few meters below the surface in most years. Growth of cottonwood tree rings has little connection to annual climatic events. However, long-lasting droughts could impact bottomland forest growth because of lower ground-water levels.

The bottomland forest experienced an anomalous increase in vegetation cover in July 1988, as indicated by NDVI values, image differencing, and the band 5:4 ratio. This increase in vegetation cover is contrary to normal expectations for drought effects and is opposite to the slight reduction in vegetation cover in the upland forest. Field observations during the drought of 2000 provide a possible explanation. During the first year of a drought episode, the floodplain surface dries up; small water bodies in meander scrolls disappear, and wetland soil begins to lose water. This allows grass and herbaceous plants to rapidly spread over the dry hollows and potholes on the forest floor. Meanwhile, ground water remains relatively close to the surface and available to tree roots. The net result is an increase in vegetation cover within the bottomland forest. Continuation of a drought during subsequent years, however, leads to soil-moisture deficit and lowered ground water, with a reduction in understory vegetation and reduced tree growth. This appears to be what happened during the drought of 1988-1989 in the bottomland forest, when NDVI values first increased slightly in 1988 and then declined abruptly in 1989.

Changes in vegetation occurred mainly along the edges of both the upland and bottomland study forests, as demonstrated by image differencing and principal- 
component analysis (figs. 27 and 28). Boundary or edge effects are well known in ecological studies of vegetation. In the case of forests, the edges are more exposed to microclimatic impact of insolation, wind stress, and temperature, which affect evapotranspiration and, thus, soil moisture. The forest interior is more protected from these microclimatic factors, which helps to preserve soil moisture. Another factor that undoubtedly affected the bottomland forest was flooding of the Missouri River in 1993. Erosion and deposition of sediment caused permanent changes in soil and topography of the floodplain. It is not surprising that the greatest changes in the bottomland forest took place next to the Missouri River channel, along the northern margin of the forest (fig. 29). Changes also happened on the western margin of the forest, where it meets the levee around the airfield.

Overall, NDVI values declined from 1987 to 1997 for all areas studied: upland and bottomland forests as well as whole-study scenes (see tables 2, 3). Human impactssuch as mowing, clearing, and construction-could be a local factor, particularly along forest margins. However, this seems an unlikely explanation for long-term decline in whole-study scene NDVI values. A more-probable explanation is connected to long-lasting climatic trends, in which the average yearly precipitation of $74 \mathrm{~cm}$ (29 in) for the period of study is well below the long-term average of $90 \mathrm{~cm}$ (35 in). Following the severe drought of 1988-1989, forest cover experienced partial recovery.
This recovery was interrupted by a minor drought in 1991-1992 and major flooding in 1993. As of 1997, forest cover had not quite recovered to the level of 1987. Given the drought of 2000, it seems likely that another decline in forest NDVI may take place in 2001.

Residual values for the TM band 5:4 ratio showed different fluctuations from the NDVI values. Residual 5:4 values increased markedly in 1989 and 1994 for both study forests (see fig. 23). The 1989 increase corresponds with the lowest mean annual precipitation and most negative PDSI value in the study period. The 1994 increase, however, is consistent with reduced tree-ring width and principal-component analysis, which suggest that both forests suffered limiting growth factors. The preceding year, 1993, experienced highest mean annual precipitation, major flooding, and lowest mean annual temperature during the period of study. On this basis, it appears the residual values for TM band 5:4 ratios may reflect current conditions as well as climatic events of the past year. The climatic significance of changes in the TM band 5:4 ratio is difficult to evaluate, as either drought or flood appears to increase residual values. However, the band 5:4 ratio is consisently higher for hardwood (upland) forest than for the cottonwood (bottomland) forest (see fig. 22). As these forest types are visually indistinguishable on the Landsat images, this ratio difference could be useful in separating and classifying similar types of forests elsewhere.

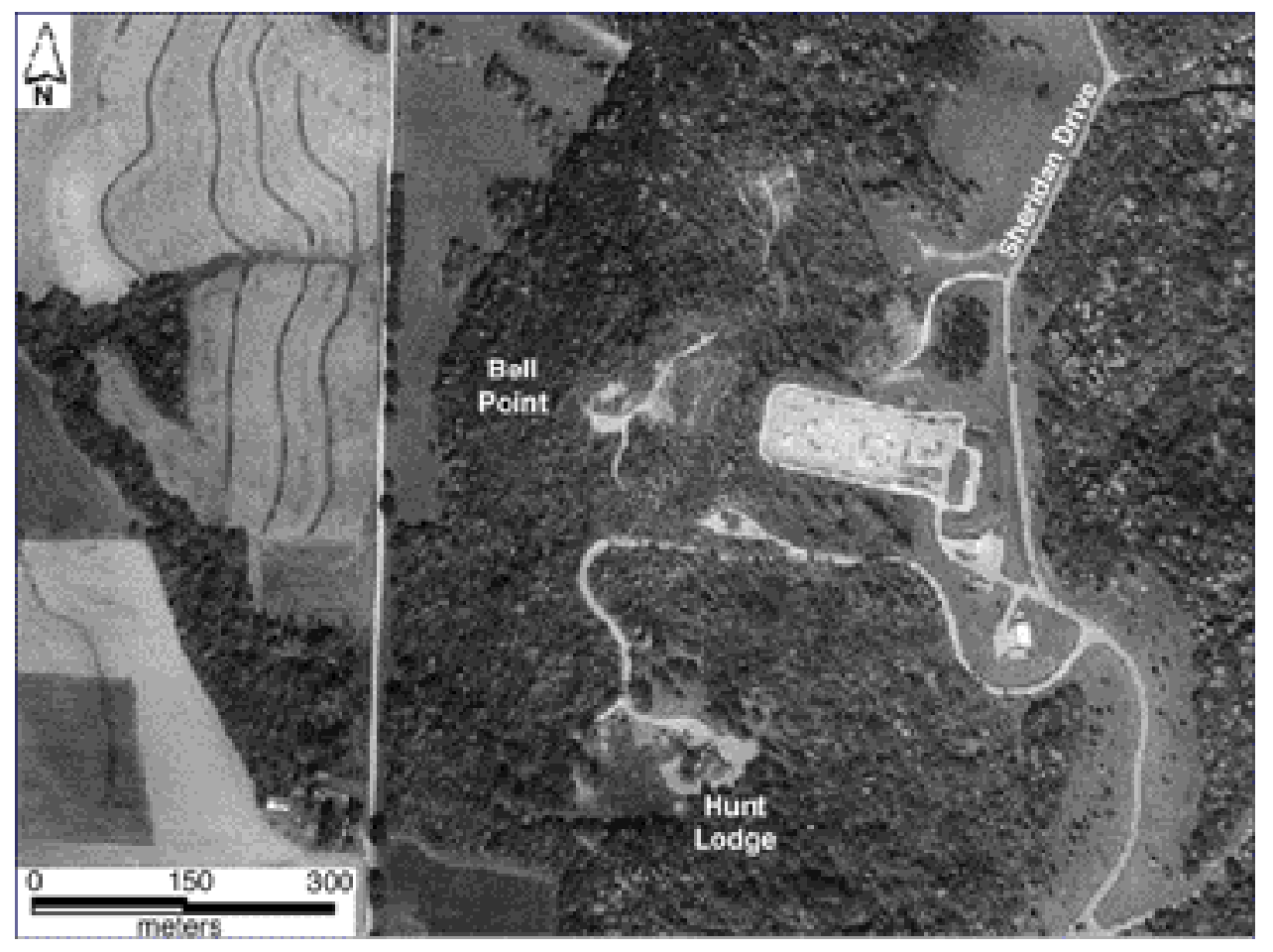

FIGURE 27. Digital orthophotograph showing the western margin of the upland study forest near Bell Point. This edge experienced significant decline during the period of study. Compare with fig. 18. 


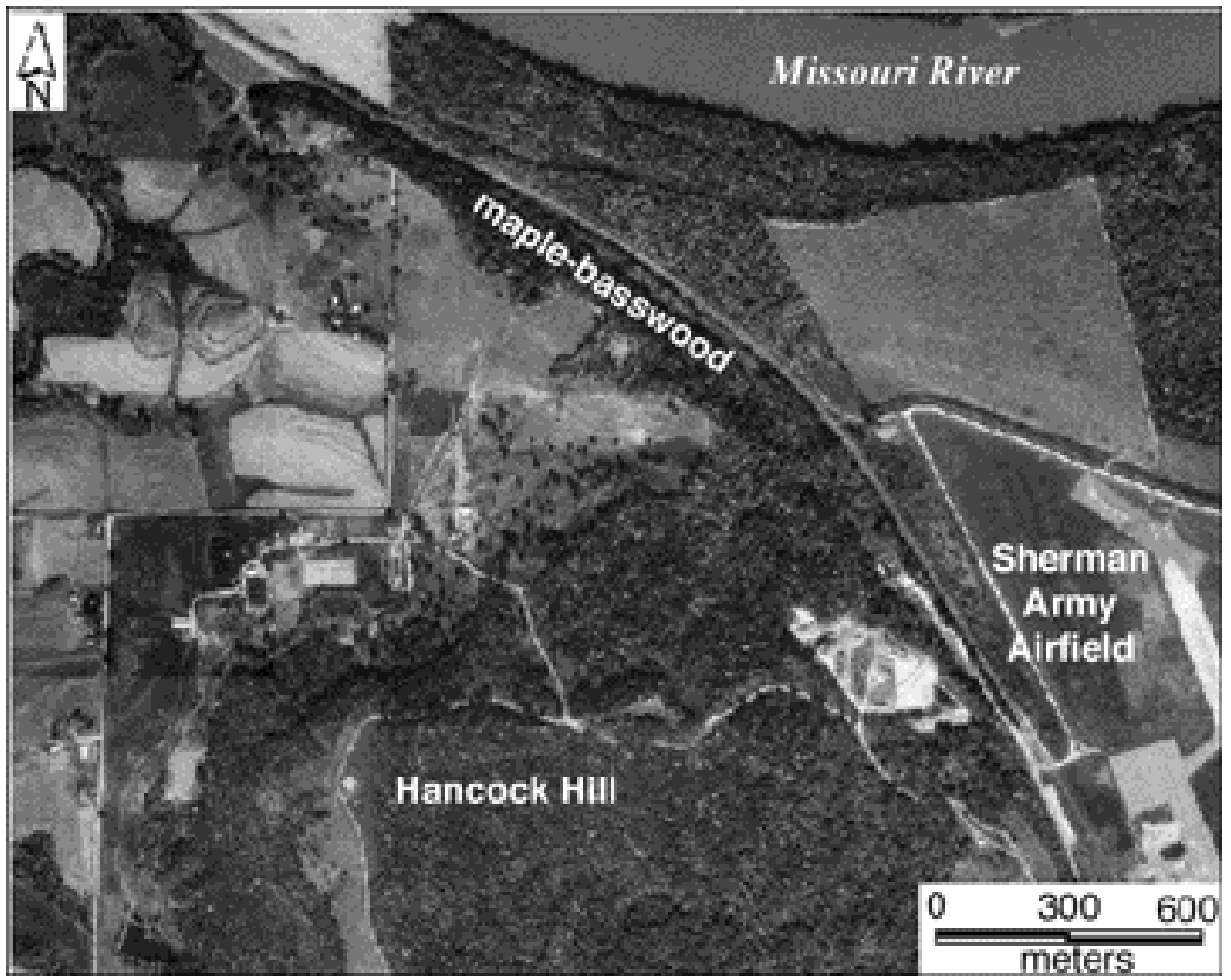

FIGURE 28. Digital orthophotograph showing the upland maple-basswood forest along the Missouri valley bluff. The western margin of this forest experienced significant decline during the period of study. Compare with fig. 18.

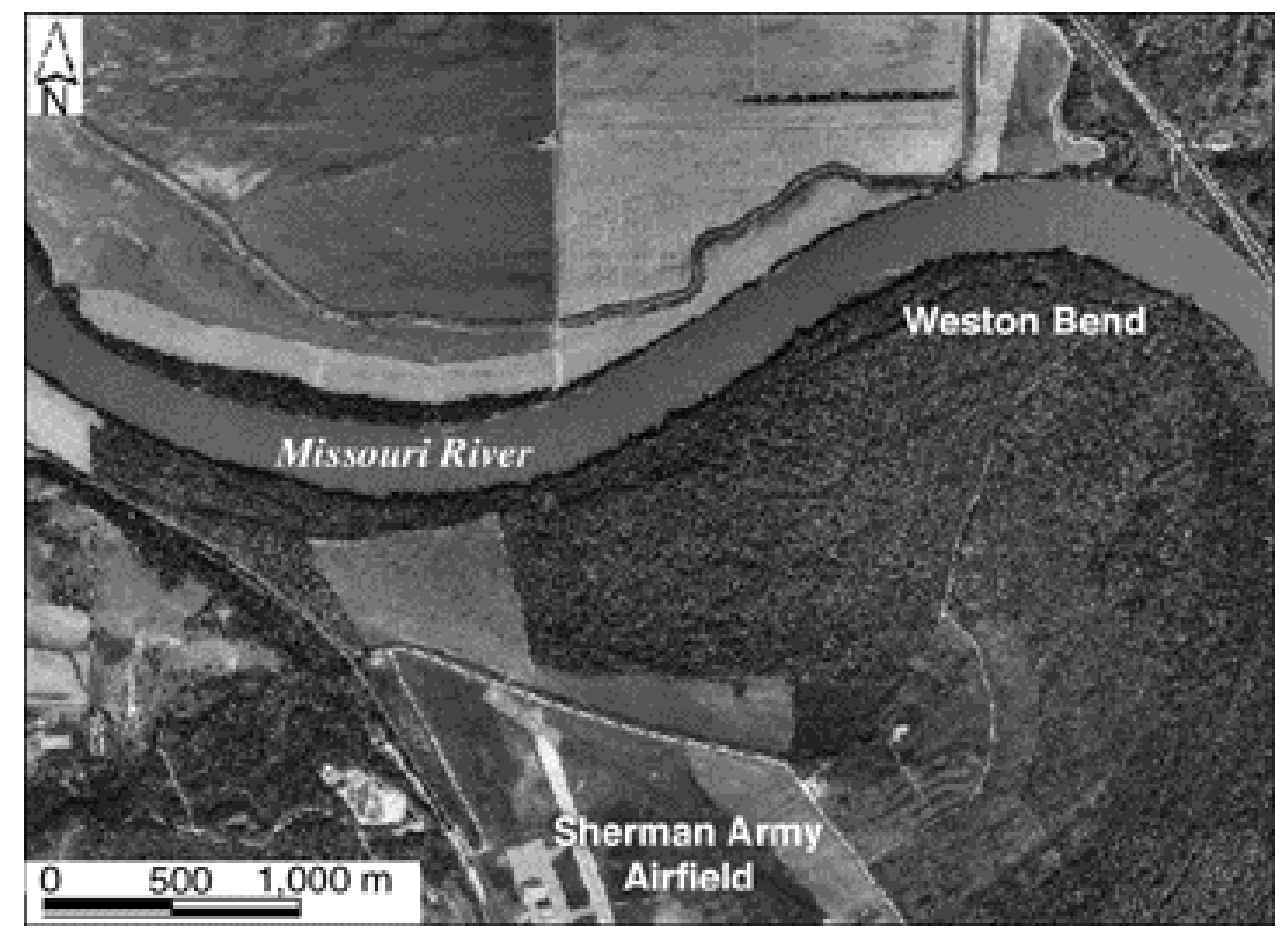

FIGURE 29. Digital orthophotograph showing the bottomland study forest. The northern margin of this forest experienced significant decline during the period of study. Changes also took place along the western margin next to the levee around the airfield. Compare with fig. 19. 
The photographs taken by KAP over the upland forest show a rough canopy with many shadows at the scale of meters (see fig. 25). These shadows would reduce values for reflected solar energy in the visible, near-infrared, and mid-infrared spectra. Such shadows are not depicted in Landsat TM imagery, for which sensor resolution is $30 \mathrm{~m}$ $(100 \mathrm{ft})$. We surmise that meter-sized shadows depress the overall reflectivity of the upland forest canopy, which would result in lower values for individual TM bands (15 and 7) and lessen the possibility for TM sensor saturation. A similar effect is likely for water-filled hollows on the floor of the bottomland forest. However, band ratios tend to remove such variations in overall brightness (Jensen, 1996), so resulting NDVI values and the band 5:4 ratio should not be adversely affected by small shadows. Although canopy roughness was considered to be more or less constant throughout the study period, differences in canopy roughness should be taken into account in comparisons of the study forests with similar forests elsewhere.

The results of intentional burning of the bottomland prairie illustrate the importance of human management techniques (see fig. 26). Controlled fire is commonly used to maintain native (warm-season) grassland ecosystems in the Great Plains region (Fitch et al., 2001). Such prairies are fire adapted and must burn occasionally to retain their natural character. Spring grassland burning has several important benefits: old, dead grass is removed, which allows rapid growth of new grass; nutrients in the old grass are returned to the soil to fertilize new growth; and woody brush and trees are inhibited from spreading into the prairie. A prairie should be burned once every three to seven years to promote maximum biodiversity and to prevent establishment of trees and brush. The bottomland prairie at Fort Leavenworth is maintained primarily by annual mowing. It had not been burned for twenty years prior to the deliberate fire of April 2000. A large volume of litter and dry vegetation had accumulated, and much brushy vegetation had grown up.

KAP depicts trees injured or killed by the fire on the edge of the bottomland forest. The fire destroyed or damaged basal bark of these trees, which cut off supply of water and nutrients from the roots, and killed some trees outright. Other injured trees were able to grow leaves in their upper branches, based on food stored in the body of the tree. Most of these trees probably did not survive a second year, although some roots may survive to sprout new trees. Field observations in June 2001 confirmed that many trees injured by fire had died (fig. 30). It is unusual for mature trees to be so adversely affected by an understory fire. In fact, it is common practice to burn the understory of upland, hardwood forests in the Chautauqua Hills (southeastern Kansas) and Missouri Ozarks. The authors have observed, however, that trees are much more susceptible to fire damage during drought years, such as 1988-1989 and 2000. Once again, it is notable that the impact of burning is most pronounced at the forest margin.

The KAP images demonstrate the effectiveness of fire for controlling tree growth and forest expansion into areas that are managed for grassland habitat. Given the rapid growth rate for cottonwood trees, it would be necessary to

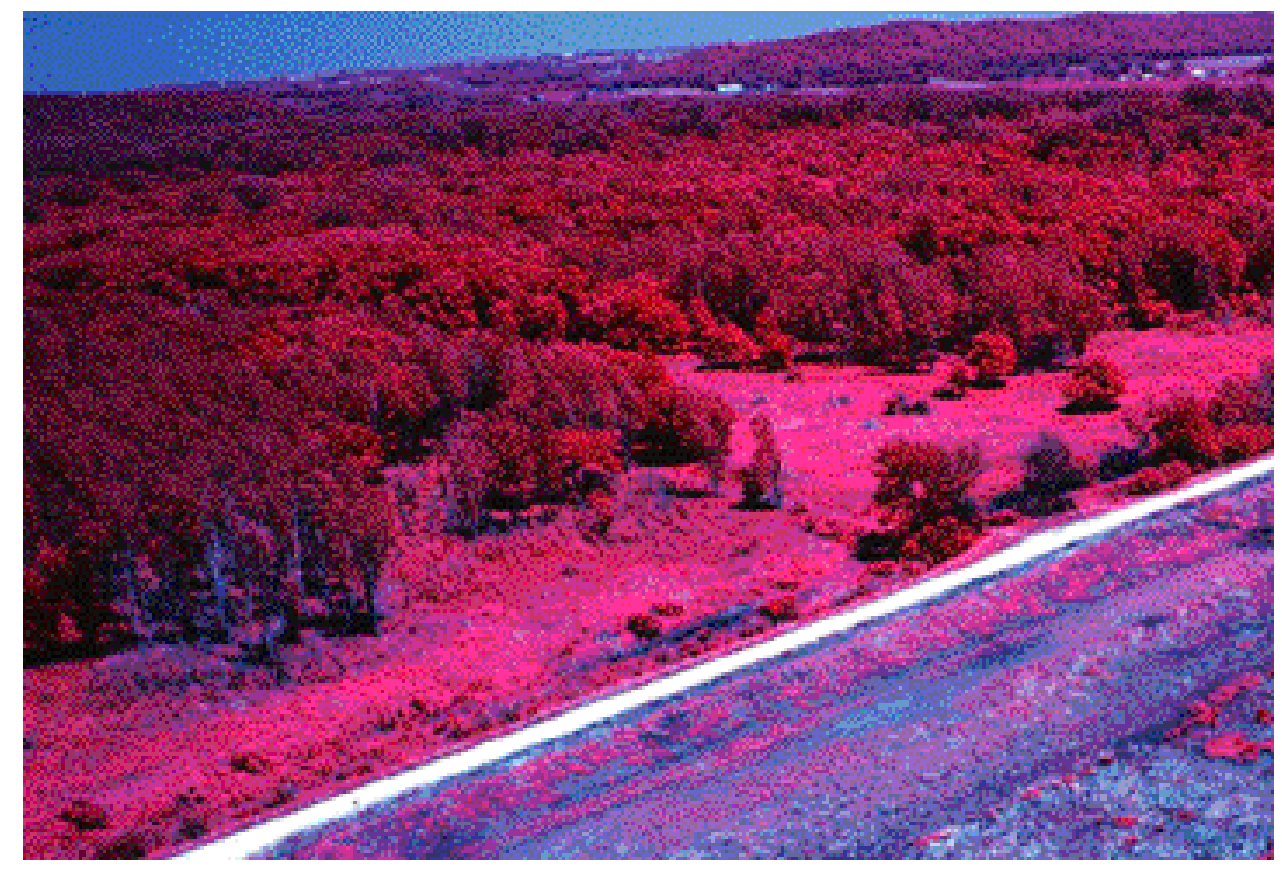

FIGURE 30. Color-infrared kite aerial photograph of the bottomland forest, June 2001. Dead trees (bare trunks) are evident at the forest margin toward the near left side of scene. Compare with Fig. 26. 
burn frequently (at least every third year) to prevent the bottomland forest from spreading farther into the prairie area. Burning in wet years would minimize damage to mature trees, but would still suppress growth of brush and young trees. Early spring burning, prior to tree flowering in early April, could also reduce potential injury to mature trees.

\section{Conclusions}

Our conclusions are based on analysis and interpretation of data derived from various sources, namely Landsat TM imagery, KAP, tree-ring cores, climatic records, and ground observations. These conclusions are specific to the upland and bottomland study forests on the Fort Leavenworth military reservation. By inference, these conclusions may be extended to other similar deciduous forests in northeastern Kansas and northwestern Missouri as well as neighboring portions of the central United States. Our main conclusions are briefly summarized below.

1. Variations of tree-ring width in oaks of the upland study forest are closely related to precipitation and PDSI for the previous year (July-June). Thus, tree-ring width is a direct indicator of current climatic conditions that affect growth of wood in the body of the tree.

2. The initial year of a drought results in a slight decline for NDVI values in the upland forest, whereas the bottomland forest experiences a slight increase for NDVI values. The latter is a result of greater understory growth infilling dry hollows and potholes. The second year of a drought leads to significant declines of NDVI values for both upland and bottomland forests. Minimal NDVI values are achieved the year after the end of a drought.

3. Variations in Landsat-derived NDVI values lag one or two years behind climatic events, because forest canopy (leaf coverage) depends on food stored in trees from previous years. Thus, NDVI values represent antecedent climatic events. Forest canopy, as portrayed by NDVI values, does not relate to current climatic factors, nor do NDVI values correspond to tree-ring growth for the same period.

4. Most year-to-year changes in NDVI values occurred on the margins of the two study forests, while forest interiors remained relatively stable during the period of study. Changes along forest boundaries are presumably the results of microclimatic stress for both forests, as well as impact of Missouri River flooding on the bottomland forest. Human activites also may have affected some forest edges.

5. NDVI values from 1987 to 1997 are slightly down in both study forests and the whole study scene. This is probably a reaction to decreased precipitation throughout the study period compared to the long-term average.

6. Residual values for the TM band 5:4 ratio are a reflection of changes in leaf moisture. The band 5:4 residual values are tied to both drought and flood episodes, so their climatic significance is difficult to interpret. The upland forest displays consistently higher band 5:4 ratios than does the bottomland forest. This relationship could be useful for identifying and classifying similar forests in other locations.

7. The upland study forest has a rough canopy in which meter-sized shadows are widely scattered. These shadows are not visible in TM images, but may likely depress individual band values. Because band ratioing (NDVI and 5:4 ratio) tends to remove such variations in brightness, and canopy roughness changed little during the period of study, the influence of canopy roughness is considered insignificant for this study.

8. Controlled burning of the bottomland prairie (April 2000) had a marked impact along the margin of the bottomland forest. Cottonwood trees on the forest edge were killed or injured by the fire; these trees were probably more susceptible to fire damage because of drought conditions.

\section{Acknowledgments}

This investigation was undertaken with primary financial support from the Kansas NASA EPSCoR research cluster on remote sensing of rural resources: see http://www.emporia.edu/nasa/epscor/. Additional financial support was provided by the Kansas Space Grant Consortium and by Emporia State University. N. Wilkins and K. Nang contributed research on methods of satelliteimage processing and tree-ring analysis. F. Pavri and S.W. Aber assisted with field observations and kite aerial photographs at the study forests. Wilkins, Nang, and several other students from Emporia State University also helped with KAP. D. G. Goodin, J. A. Harrington, Jr., and M. E. Ramspott reviewed the article and offered valuable suggestions for improvements.

\section{References}

Aber, J. S., Aber, S. W., and Leffler, B. 2001, Challenge of infrared kite aerial photography: Transactions of the Kansas Academy of Science, v. 104(1/2), p. 18-27 (abstract available online: http://www.emporia.edu/kas//trans104/ aber1.htm).

Aber, J. S., Sobieski, R., Distler, D. A., and Nowak, M. C., 1999, Kite aerial photography for environmental site investigations in Kansas: Transactions of the Kansas Academy of Science, v. 102, p. 57-67 (abstract available online: http://www.emporia.edu/kas/trans102/ trans102.htm\#aber).

Aber, J. S., Nang, K. N., Wilkins, N., Hengchun Ye, Harrington, J., and Nowak, M. C., 1998, Remote sensing of forest growth and response to climatic variations in northeastern Kansas, U.S.A.: 27th International Symposium on Remote Sensing of Environment, Proceedings, Troms $\varnothing$, Norway, June 8-12, 1998, p. 709-714.

Allen, W. A., and Richardson, A. J., 1968, Interaction of light with a plant canopy: Journal of the Optical Society of America, v. 58, p. 1,023-1,028. 
Asrar, G., and Dozier, J., 1994, EOS science strategy for the earth observing system: AIP Press, American Institute of Physics, 119 p.

Avery, T. E., and Berlin, L. B., 1992, Fundamentals of remote sensing and airphoto interpretation: New York, Macmillan, $472 \mathrm{p}$.

Blasing, T. J., and Duvick, D., 1984, Reconstruction of precipitation history in North American corn belt using treerings: Nature, v. 307, p. 143-145.

Brumwell, M. J., 1951, An ecological survey of the Fort Leavenworth military reservation: American Midland Naturalist, v. 45, p. 187-231.

Carter, G. A., 1991, Primary and secondary effects of water content on the spectral reflectance of leaves: American Journal of Botany, v. 78, p. 916-924.

Cibula, W. G., Zetka, E. F., and Rickman, D. L., 1992, Response of Thematic Mapper bands to plant water stress: International Journal of Remote Sensing, v. 13, p. 1,8691,880 .

Colwell, J. E., 1974, Vegetation canopy reflectance: Remote Sensing of Environment, v. 3, p. 175-183.

Cook, E. R., Kablack, M. A., and Jacoby, G. C., 1988, The 1986 drought in the southeastern United States-How rare an event was it?: Journal of Geophysical Research v. 93, D11, p. $14,257-14,260$.

Davenport, M. L., and Nicholson, S. E., 1990, On the relation between rainfall and the Normalized Difference Vegetation Index for diverse vegetation types in East Africa: International Journal of Remote Sensing, v. 14, p. 2,3692,389 .

Eastman, J. R., McKendry, J. E., and Fulk, M. A., 1995, UNITAR Explorations in Geographic Information Systems Technology, Vol. 1, Change and time series analysis: Worcester, Massachusetts, Clark Labs, Clark University, $121 \mathrm{p}$.

Fitch, H. S., Von Achen, P., and Echelle, A. F., 2001, A half century of forest invasion on a natural area in northeastern Kansas: Transactions of the Kansas Academy of Science, v. 104 (abstract available online: http://www.emporia.edu/kas/ trans104/trans104.htm\#fitch).

Freeman, C. C., Busby, W. H., Lauver, L. L., Kindscher, K., Elliott, J., and Eifler, D. A., 1997, A natural areas inventory of the Fort Leavenworth military reservation, Leavenworth County, Kansas: State Biological Survey of Kansas, Report 77, $246 \mathrm{p}$.

Fritts, H. C., 1976, Tree Rings and Climate: New York, Academic Press, 567 p.

Gates, D. M., Keegan, H. J., Schleter, J. C., 1965, Spectral properties of plants: Applied Optics, v. 4, p. 11-20.

Hunt, R. E., Jr., and Rock, B. N., 1989, Detection of changes in leaf water content using near- and middle-infrared reflectances: Remote Sensing of Environment, v. 30, p. 43-54.
Jensen, J. R., 1996, Introductory Digital Image Processing-A remote sensing perspective: New Jersey, Prentice-Hall, $316 \mathrm{p}$.

Kuchler, A. W., 1974, A new vegetation map for Kansas: Ecology, v. 55, p. 586-604.

Nang, K. N., 1998, Remote sensing and tree-ring study of forest conditions in northeastern Kansas: unpublished master's thesis, Emporia State University, Kansas, 67 p.

NADC, 1999, Get/View online climatic data and weather observations: National Climatic Data Center (http:// www.ncdc.noaa.gov/ol/climate/climatedata.html).

Palmer, W. C., 1965, Meteorological drought: U.S. Weather Bureau, Research Paper 45, Washington, D.C.

Perry, C. R., Jr., and Lautenschlager, L. F., 1984, Functional equivalence of spectral vegetation indices: Remote Sensing of Environment, v. 14, p. 169-182.

Pinder, J. E., III, and McLeod, K. W., 1999, Indications of relative drought stress in longleaf pine from Thematic Mapper data: Photogrammetric Engineering and Remote Sensing, v. 65, p. 495-501.

Price, J. C., and Bausch, W. C., 1995, Leaf area index estimation from visible and near-infrared reflectance data: Remote Sensing Environment, v. 52, p. 55-65.

Rock, B. N., Vogelmann, J. E., Williams, D. L., Vogelmann, A. F., and Hoshizaki, T., 1986, Remote detection of forest damage: Bioscience, v. 36, p. 439-445.

Rouse, J. W., Jr., Haas, R. H., Deering, D. W., Schell, J. A., and Harlan, J. C., 1974, Monitoring the vernal advancement and retrogradation (green wave effect) of natural vegetation, NASA/GSFC type III final report: Greenbelt, Maryland, NASA, $371 \mathrm{p}$.

Stockton, C. W., and Meko, M. M., 1975, A long-term history of drought occurrence in western United States as inferred from tree rings: Weatherwise, v. 28, p. 244-250.

Tucker, C. J., 1979, Red and photographic infrared linear combinations for monitoring vegetation: Remote Sensing of Environment, v. 8, p. 127-150.

1980, Remote sensing of leaf water content in the nearinfrared: Remote Sensing of Environment, v. 10, p. 23-32.

Wallace, J. A., 2000, Temporal studies of deciduous forests in northeastern Kansas using Landsat Thematic Mapper images: unpublished master's thesis, Emporia State University, Kansas, 146 p.

Wang, J., Price, K. P., and Rich, P. M., 2001, Spatial patterns of NDVI in response to precipitation and temperature in the central Great Plains: International Journal of Remote Sensing 22, no. 18, p. 3,827-3,844.

Wilkins, N. H., 1997, Analysis of forest change at Fort Leavenworth, Kansas, using Landsat Thematic Mapper data: unpublished master's thesis, Emporia State University, Kansas, 83 p. 